Clim. Past Discuss., doi:10.5194/cp-2017-24, 2017

Manuscript under review for journal Clim. Past

Discussion started: 31 March 2017

(c) Author(s) 2017. CC-BY 3.0 License.

\title{
The Indian summer monsoon climate during the Last Millennium, as simulated by the PMIP3
}

\section{Charan Teja Tejavath ${ }^{\mathrm{a}}$, Karumuri Ashok ${ }^{\mathrm{a}}$, Supriyo Chakraborty ${ }^{\mathrm{b}}$ and Rengaswamy $\operatorname{Ramesh}^{\mathrm{c}}$}

${ }^{a}$ University centre for Earth and Space Sciences, University of Hyderabad, Hyderabad, India.

${ }^{\mathrm{b}}$ Indian Institute of Science and Tropical Meteorology, Pune, India.

${ }^{\mathrm{c}}$ School of Earth and Planetary Sciences, NISER, Bhubaneswar, India

10

\section{Abstract}

Here, using the available model simulations from the PMIP3, we study the mean summer (JuneSeptember; JJAS) climate and its variability in India during the Last Millennium (CE 850-1849; LM) for

15 which instrumental observations are unavailable, with emphasis on the Medieval Warm Period (MWP; CE 1000-1199 as against the CE 950-AD1350 from the proxy-observations) and Little Ice Age (LIA; CE 15501749 as against the CE 1500-1850 from proxy observations). Out of the eight available models, by validating the corresponding simulated global and Indian mean summer temperatures and mean Indian summer monsoon rainfall (ISMR), and their respective trends, from historical simulations (CMIP5) against

20 the various observed/reanalysed datasets for the 1901-2005 period. From this exercise, we identify seven 'realistic' models.

The models simulate higher (lower) mean summer temperatures in India as well as globally during the MWP (LIA) as compared to the corresponding LM statistics, in confirmation of several proxy data sets. Our Analysis shows a strong negative correlation between the NINO3.4 index and the ISMR and a positive correlation between NINO3.4 and summer temperature over India during the LM, as is observed in the last one-and-half centuries. The magnitude of the simulated ISMR-NINO3.4 index correlations, as seen from the multi-model mean, is found to be higher for the MWP (-0.19; significant at 0.05 level) as compared to that for the LIA (-0.09; insignificant). Our analysis also shows that the above (below) LM-mean summer temperatures during the MWP (LIA) are associated with relatively higher (lower) number of concurrent El Niños as compared to the La Niñas. Distribution of boreal summer velocity potential at $850 \mathrm{hPa}$ in the central tropical pacific and a zone of anomalous convergence in the central tropical pacific, flanked by two zones of divergence in the equatorial pacific, suggesting a westward shift in Walker circulation as compared to the current day signal. The anomalous divergence centre in the west also extends into the 
Clim. Past Discuss., doi:10.5194/cp-2017-24, 2017

Manuscript under review for journal Clim. Past

Discussion started: 31 March 2017

(c) Author(s) 2017. CC-BY 3.0 License.

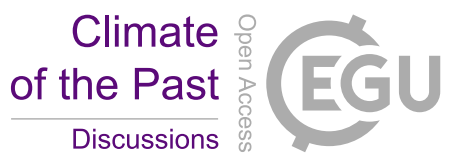

equatorial eastern Indian Ocean, which results in an anomalous convergence zone over India and therefore excess rainfall during the MWP as compared to the LM. The results are qualitative, given the inter-model spread.

\section{Introduction}

Instrumental records of climate seldom date back prior to the 1850s. Therefore, analysis of proxy climate data, aided by climate modelling, has been the principal means to evaluate past climate variability. Past climate records exhibit significant variability on millennial to inter-annual time scales (IPCC, 2013).

10 Interestingly, this IPCC report based on a review of several publications, points out significant centennial climate variations during the last two millennia, though there is no apparently significant change in the external climate forcing from the first half of 20th century. Paleo-data based studies such as those by Lamb, 1965; Grove, 1988; Graham et al., 2010 identify two significant events in the last millennium (LM) prior to the period when instrumental observations stated, i.e. Common Era (CE) 850-1849. These are, (i) a

15 relatively warmer period known in literature as the 'Medieval Warm Period' (MWP, CE 950-1350), roughly followed by (ii) a relatively cooler period, the Little Ice Age (LIA, CE 1500 - 1850). Presence of these warmer (MWP) and cooler (LIA) periods varies from region to region, in terms of timing, duration and magnitude of the temperature anomalies.

Paleoclimate reconstructions from various well-dated proxy data suggest that during the MWP, some regions experienced temperatures as warm as mid- $20^{\text {th }}$ century whereas some others were as warm as the late-20 ${ }^{\text {th }}$ century (e.g., IPCC 2013, Prasad and Enzel, 2006; Fleitmann et al., 2007; Borgaonkar et al., 2010; Ponton et al., 2012).

The Indian Summer Monsoon Rainfall (ISMR; June-September; JJAS) variability is manifested on intraannual, inter-annual, decadal, centennial and millennial to multi-millennial time scales (Ramesh et al., 2011). Paleo-monsoon records from well-dated proxy data show centennial-to millennial-scale changes in the ISMR during the Holocene: from the Arabian Sea (e.g. Sarkar et al., 2000; Gupta et al., 2003; Staubwasser et al., 2003; Tiwari et al., 2005), the Arabian Peninsula (e.g. Fleitmann et al., 2007; Fleitmann

30 et al., 2003;Neff et al., 2001), and the Indian sub- continent (e.g. Berkelhammer et al., 2012; Dixit et al., 2015; Dixit et al., 2014a; Dixit et al., 2014b; Dixit, 2013; Dutt et al., 2015; Nakamura et al., 2015).

In a recent review, Dixit and Tandon (2016) suggest that MWP and LIA effects are well reflected in the ISMR, with a caveat that proxy data exhibit heterogeneity in terms of the timing and duration. Proxy 
Clim. Past Discuss., doi:10.5194/cp-2017-24, 2017

Manuscript under review for journal Clim. Past

Discussion started: 31 March 2017

(c) Author(s) 2017. CC-BY 3.0 License.

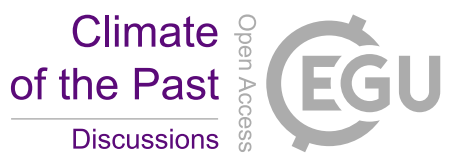

records also suggest that, by and large, during the last millennium, ISMR was the highest during the MWP and relatively weaker during the LIA (Yadava et al., 2005). However, the data density is rather sparse in time and space to quantify the decadal scale temporal structure of ISMR variability during MWP and LIA.

A speleothem-based reconstruction of ISMR variability by Sinha et al., (2007) exhibits an evolution conforming to solar activity (a surrogate for which is radiocarbon activity) only during the MWP. An increased summer monsoon precipitation during the MWP is suggested to be linked to the ENSOmodulated solar forcing in proxy studies by Berkelhammer et al., (2010) and Emile-Geay et al., (2007). The speleothem-based monsoon reconstruction of Sinha et al., (2007 and 2011) suggests a severe

10 weakening of ISM (Indian Summer Monsoon) during the LIA, apparently associated with (multi-year to decades long duration of) droughts particularly between $13^{\text {th }}$ and $17^{\text {th }}$ centuries. Another proxy record, from the Dandak cave in Central India, shows a 30\% rainfall reduction during the $14^{\text {th }}$ century (Yadava, et al., 2005).

Obviously, the recent $\sim 150$-year period is the best documented period in terms of instrumental observations. Uncertainties, however, exist in terms of the quality and spatial density of data even for this period.

The observational records of ISMR from the beginning of last century show that its inter-annual and inter-decadal variability is significantly associated with that of the El Niño-Southern Oscillation (ENSO). Typically, the warmer (cooler) ENSO events are associated with lesser (higher) than normal rain over India during the boreal summer, concurrent with the Indian monsoon season. Prasad et al. (2014) infer that the long-term influence of ENSO like conditions on ISM began only $2 \mathrm{ky}$ BP, and is coincident with Southern Indo-Pacific warm pool (IPWP) warming, based on proxy climate data. They also suggest that the IPWPISM links and large scale advection of moist air toward India varies on a multi-centennial scales. Kitoh et al. (2007), in a model study, observed decadal variability in the ENSO-ISM relation. Through a 31-yr moving correlation analysis, they show that, during the LM, monsoon-ENSO correlations vary over a wide range, specifically -0.71 to +0.07 , with an overall correlation of -0.34 for the $L M$.

Thus, the variability of Indian summer monsoon during the LM has been relatively less studied, particularly from the modelling perspective. It is also noticeable that all the model studies cited above primarily employed single GCMs. From this perspective, it is interesting to explore multi-model simulations such as those from the PMIP3, to study Indian summer monsoon conditions during the LM, specifically the MWP and the LIA, and examine whether these model results could be reconciled with 
Clim. Past Discuss., doi:10.5194/cp-2017-24, 2017

Manuscript under review for journal Clim. Past

Discussion started: 31 March 2017

(c) Author(s) 2017. CC-BY 3.0 License.

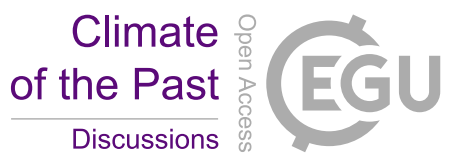

proxy-observations. Likewise, such a study highlights the capability of these models in capturing at least a millennium of the past climate with fidelity, in addition to facilitating a quantification of the multi-model spread. Furthermore, such a study would serve as a benchmark for addressing longer periods of climate variability relevant to the Indian summer monsoon using models.

5

With this motivation, here we study the multi-model simulated ISMR variability and its teleconnections with the ENSO during the LM, using various relevant PMIP3 datasets with an emphasis on the Medieval Warm Period (MWP; CE 1000-1199) and Little Ice Age (LIA; CE 1550-1749). We consider 200 warmest (relatively coldest) years from MWP (LIA) for maintaining uniformity between global and

10 regional analysis of ENSO-ISM teleconnections from CMIP5 LM simulations, with the knowledge that the signatures of the MWP and LIA varied from region to region, at least in terms of magnitude (e.g. Dixit and Tandon 2016).

In the following sections, we describe the various reanalysed, observed, and PMIP3 datasets we used, present our results subsequently, and finally provide a concluding summary.

\section{Data and Methodology}

It is indeed a challenging prospect to validate the PMIP3 simulations for the LM period over India

20 given the sparse and scanty observations. Fortunately, model simulations of the CMIP5 for the historical period (CE 1850-2005) can be validated using various observed/reanalysed gridded datasets, keeping in mind the uncertainties associated with such datasets during the pre-satellite period. Therefore, in this study, we start by exploring the fidelity of simulated Indian summer monsoon climate from historical simulations (henceforth referred to as HS) that cover the CE 1850-2005 period for which instrumental observations are

25 available. It may be noted that this exercise is carried out only for eight CMIP5 models for which the PMIP3 simulations for the LM period are available for the CE 850-1849 period (LM), under the class termed as 'past1000 (henceforth referred to as p1000)'.

From the HS, the models were forced using the observed atmospheric composition changes with 30 natural aerosols or their precursors, and natural sources of short-lived species, and time-evolving land cover as outlined by Taylor et al. (2012). On the other hand, the p1000 results were obtained by forcing the models with well-mixed greenhouse gases, changes in volcanic aerosols, land use, and solar irradiance changes (Taylor et al, 2012). We evaluate the fidelity of the HS simulations by comparing with the observed/reanalysed Indian summer monsoon rainfall and air temperature. This helps us to identify the 
Clim. Past Discuss., doi:10.5194/cp-2017-24, 2017

Manuscript under review for journal Clim. Past

Discussion started: 31 March 2017

(c) Author(s) 2017. CC-BY 3.0 License.

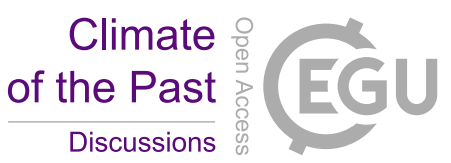

'good' PMIP3 models for further analysis. The seven models whose data used in this study are: BCCCSM-1-1(m), IPSL-CM5A-LR，FGOALS-s2，MIROC-ESM，MPI-ESM-P，GISS-E2-R，CCSM4 and HadCM3. These datasets have been downloaded from "http://cera-www.dkrz.de/WDCC/ui/Index.jsp". The acronyms used and details for these datasets are presented in Table-1; various observational/reanalysed data sets used for the validation of the HS are, the Hadley Centre Interpolated sea surface temperature (HadISST; Titchner and Rayner, 2014) for CE 1870-2014, the Extended Reconstructed Interim skin temperature, sea surface temperature and $2 \mathrm{~m}$ air temperature (ERA-Interim SKT, SST and T2M; Hersbach et al. 2015) available for CE 1900 to 2010. We also use the India Meteorological Department (IMD) gridded rainfall datasets for CE 1901-2009 period, available at $1.0^{\circ}$ latitude x $1.0^{\circ}$ longitude resolution

10 and covering the land region bound by $66.5^{\circ} \mathrm{E}-101.5^{\circ} \mathrm{E} ; 6.5^{\circ} \mathrm{N}-39.5^{\circ} \mathrm{N}$ (Rajeevan et al., 2006). For uniformity, all the simulated precipitation and near air surface temperature data sets were re-gridded to $2.0^{\circ}$ latitude $\times 2.0^{\circ}$ longitude resolution grids.

Table 1:- CMIP5/PMIP3 Last Millennium and Historical simulations, their acronyms and temporal coverage.

\begin{tabular}{|l|l|l|l|l|}
\hline S No & $\begin{array}{l}\text { CMIP5/PMIP3 } \\
\text { Models }\end{array}$ & $\begin{array}{l}\text { p1000 (Last Millennium) simulation } \\
\text { temporal coverage }\end{array}$ & Historical simulation temporal coverage & Acronyms \\
\hline 1 & BCC-CSM-1-1(m) & CE 0850-1849 & CE 1850 -2005 & BCC \\
\hline 2 & CCSM4 & CE 0850-1849 & CE 1850 -2005 & CCSM4 \\
\hline 3 & IPSL-CM5A-LR & CE 0850-1849 & CE 1850 -2005 & IPSL \\
\hline 4 & MIROC-ESM & CE 0850-1849 & CE 1850 -2005 & MIROC \\
\hline 5 & MPI-ESM-P & CE 0850-1849 & CE 1850 -2005 & MPI \\
\hline 6 & GISS-E2-R & CE 0850-1849 & CE 1850 -2005 & GISS \\
\hline 7 & FGOALS-s2 & CE 0850-1849 & CE $1850-2005$ & S2 \\
\hline 8 & HadCM3 & CE 0850-1849 & CE $1850-2005$ & HADCM3 \\
\hline
\end{tabular}

Given that model results exhibit significant variance, multi-model averaging is a well-accepted method to reduce the model biases and derive a consensus estimate. We therefore use the multi-model mean statistics as a part of the validation of the CMIP5 simulations. Unfortunately, from an analysis of the globally averaged temperature from the LM simulations, which will be discussed in more detail in section 3.2, it is apparent that the MIROC-ESM simulates a strong increasing trend in globally-averaged temperature (Figure 4), which is in disagreement with the evolution of the corresponding parameter by the other models. Nor is such a strong trend observable in proxy data (see Box TS.5, Figure-1 of Technical Summary in the IPCC 2013; Stocker 2013). Therefore, this model is not used in generating our multimodel mean (MMM) statistics.

Thus, the historical simulations are validated by comparing various climate statistics from the MMM with the corresponding climate statistics from observed and reanalysed datasets for the CE 1901- 
Clim. Past Discuss., doi:10.5194/cp-2017-24, 2017

Manuscript under review for journal Clim. Past

Discussion started: 31 March 2017

(c) Author(s) 2017. CC-BY 3.0 License.

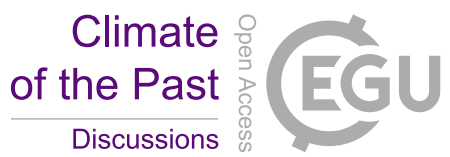

2005 period. Subsequently, we also discuss multi-model mean statistics with these models for the p1000 simulations.

We use the NINO3.4 index, an area-averaged SST over the region bound by $170^{\circ} \mathrm{E}-240^{\circ} \mathrm{W} ; 5^{\circ} \mathrm{S}-$

$5 \quad 5^{\circ} \mathrm{N}$. An The Indian summer monsoon rainfall (ISMR) index is obtained by area-averaging the mean Junethrough-September (JJAS) rainfall over the land region bound by $65^{\circ} \mathrm{E}-95^{\circ} \mathrm{E} ; 10^{\circ} \mathrm{N}-30^{\circ} \mathrm{N}$.

One must be aware that individual ENSO events may not occur at the same time in across all models, and consequently, the variance of the MMM ENSO index (such as Nino3.4 index) may decrease.

10 Indeed, as can be seen later, the standard deviation of the Nino3.4 index from the Multi-model mean (MMM) is $0.3 \mathrm{C}$ as against the $\sim 0.45 \mathrm{C}$ for the index from individual models (Tables 4 and 7 ). Having said that, studies such as the Lewis \& Legrande (2015), and Power et al., (2013) use MMM to demonstrate that the ENSO is still associated with the dominant EOF mode (e.g. Power et al., 2013) as well as its teleconnections (Lewis \& Legrande 2015). The ENSO events simulated by the MMM are obviously very

15 strong, and are robust to the "noise" from other concurrent model signals which could be neutral or even opposite-phased.

To check the ENSO-ISM relations during LM and to identify any significant interannual climate events during LM, we calculate the monthly anomalies of surface temperature and precipitation from their

20 respective climatological monthly means. The anomalies of any parameter, such as, say, JJAS temperature, for each model have been obtained by subtracting the 1000-year climatological value from the individual seasonal values. Linear correlation analysis is used to estimate the ENSO-ISMR relationship during various periods.

\section{Results}

\subsection{Validation of the $\mathrm{HS}$}

Figure $1 \mathrm{a}$ and $1 \mathrm{~b}$ respectively show a 11-year running mean of globally-averaged near surface air temperature from the eight models of the HS, along with the same from the MMM constituted by the seven models (as explained in the previous section); Figure 1c and 1d show the corresponding time series of anomalies (from the 11-year mean from the individual models as well as the MMM. It is seen from Figures $1 \mathrm{c}$ and $1 \mathrm{~d}$ that all the models are able to simulate the observed increasing temperature trend reasonably, notwithstanding an inter-model spread. Further, we find that the observed as well as and the simulated trends are significantly above the corresponding interannual standard deviations (e.g. Figure 
Clim. Past Discuss., doi:10.5194/cp-2017-24, 2017

Manuscript under review for journal Clim. Past

Discussion started: 31 March 2017

(c) Author(s) 2017. CC-BY 3.0 License.

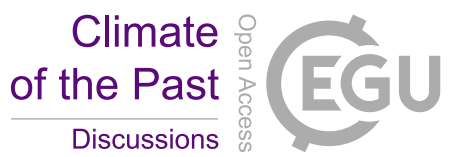

SPM.1a; Figure TS. 1; Figure TS. 9; Stocker et al., 2013; IPCC, 2013;). The Figure1d suggests that the surface temperatures over India also have continued to rise as we step into the $21^{\text {st }}$ century, which is in agreement with observations (Revadekar et al., 2012).
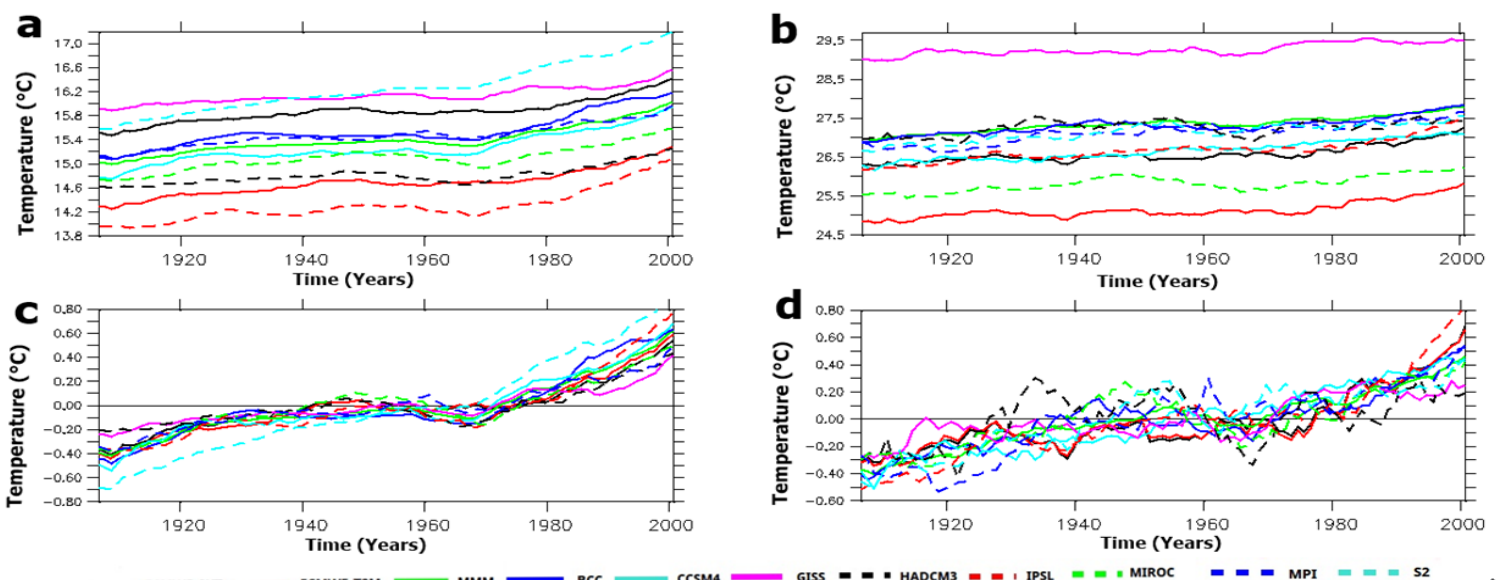

Figure 1:- 11-year running means surface air temperature $\left({ }^{0} \mathrm{C}\right)$ (a) Global (b) Over India.

Corresponding temperature anomalies $\left({ }^{0} \mathrm{C}\right)(\boldsymbol{c})$ Global (d) Over India.

On a different note, an increase in warm ENSO events, be it canonical or Modoki (e.g. Ashok et al., 2007), has been observed in the late 20 century with an increase in global temperature (e.g. Collin 2000;

10 Cai et al. 2015). The models are able to reproduce this trend qualitatively to a reasonable extent, as seen by the higher number of simulated warm events, represented by the positive Nino3.4 index (Figure 2c and Figure 2d).

Several recent studies suggest a decreasing trend in Indian summer monsoon rainfall (e.g.

15 Guhathakurtha et al., 2007; Krishnan et al., 2016; Sano et al., 2011) in recent decades. Figure 2a shows the inter-model spread across the models with the corresponding observations. We find a decreasing rainfall trend over the Indian summer monsoon region, in qualitative agreement with such a trend derived from the observations. Such a decrease in rainfall is in agreement with the observations.

Of course, the ENSO is known to be major driver of interannual variability of the Indian summer climate. This is evidenced by the negative correlation of -0.50 (Figure $3 \mathrm{a}$ ) between the time series of ISMR and NINO3.4 index for CE 1901-2005, statistically significant at 0.01 level from a 2-tailed Student's t-test. The corresponding correlations from the HS are also presented in Figure 3a. Six out of the eight models the models simulate the negative correlations that are statistically significant at 0.1 levels from a 2-tailed 
Clim. Past Discuss., doi:10.5194/cp-2017-24, 2017

Manuscript under review for journal Clim. Past

Discussion started: 31 March 2017

(c) Author(s) 2017. CC-BY 3.0 License.

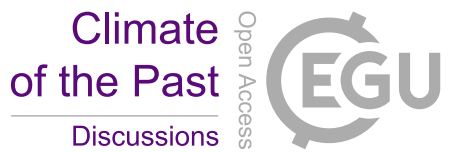

Student's t-test. For correlations from five of these, the correlations are also significant at 0.05 levels. The FGOALS-s2 simulates a very weak ISMR-NINO3.4 index correlation of 0.1 , while that from the MIROC Model is an unrealistic 0.3
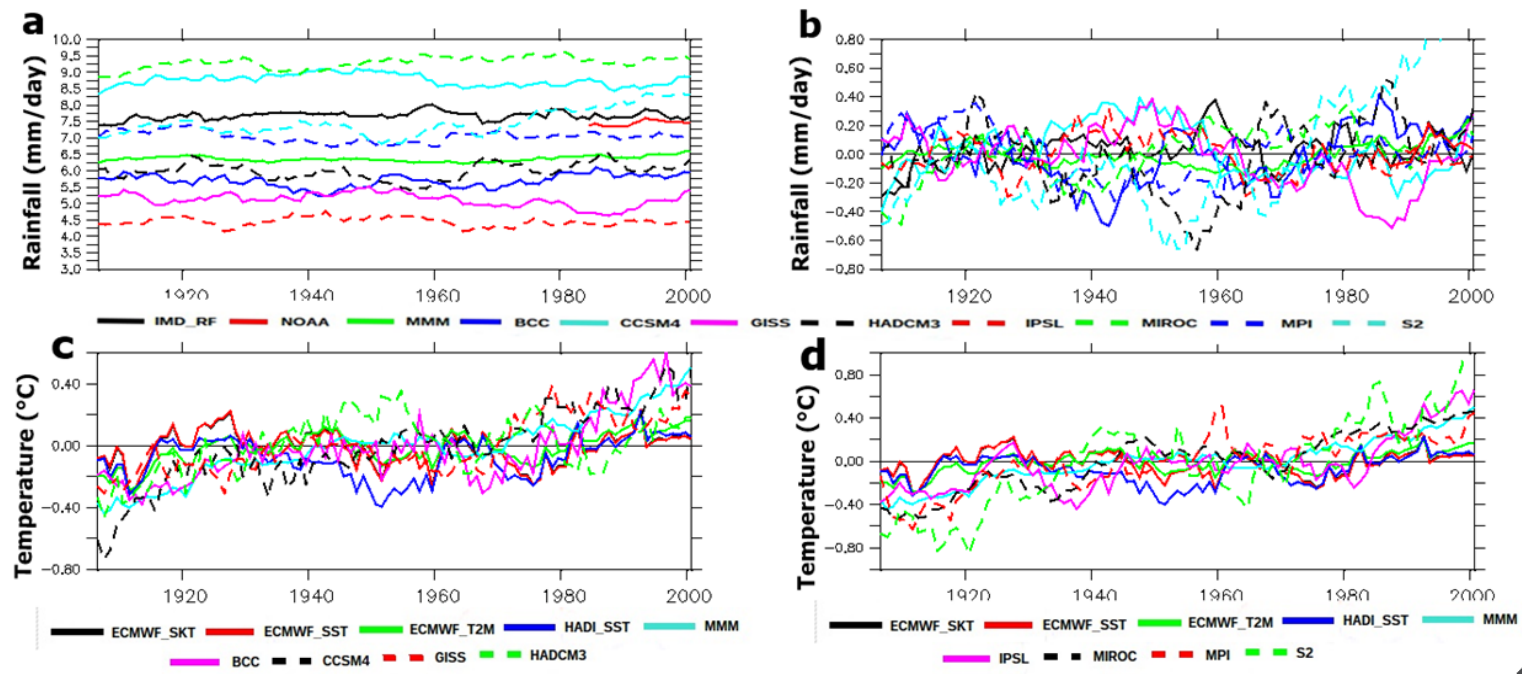

Figure 2:- (a) 11-year running mean of ISMR (mm/day) during the 1901-2005 (b) corresponding anomaly (mm/day) (c) Observed time series of NINO3.4 index, along with that from the HS of 4 models ( units are $\left.{ }^{\circ} \mathrm{C}\right) .(\mathrm{d})$ same as Figure $2 \mathrm{c}$ but from the HS remaining four models. Note that, the model time series of the NINO3.4 has been split into two panels for clarity.

The observed correlation of Indian summer temperature with the NINO3.4 index for CE 1901-2005 is a moderate 0.34 , which is statistically significant at 0.05 levels from a 2-tailed Student's t-test. MMM also reproduces this positive relationship, but with a wide range of values varying from 0.13 to 0.74 (Figure $3 b$ ); correlations for seven (five) models are statistically significant at $0.1(0.05)$ level from a 2-tailed test. ENSO relation to the JJAS temperature and/or rainfall qualitatively well. More importantly, Figures 1 and 2 show that these models are also able to capture the long term trends in the summer monsoon rainfall and temperature. Further, the interannual standard deviation for these two parameters from observations as well as from the individual model simulations are presented in Table 2. We find that simulated standard deviations from various models fall within a $\pm 20 \%$ range of observations. 
Clim. Past Discuss., doi:10.5194/cp-2017-24, 2017

Climate

Manuscript under review for journal Clim. Past

Discussion started: 31 March 2017

(c) Author(s) 2017. CC-BY 3.0 License.

a

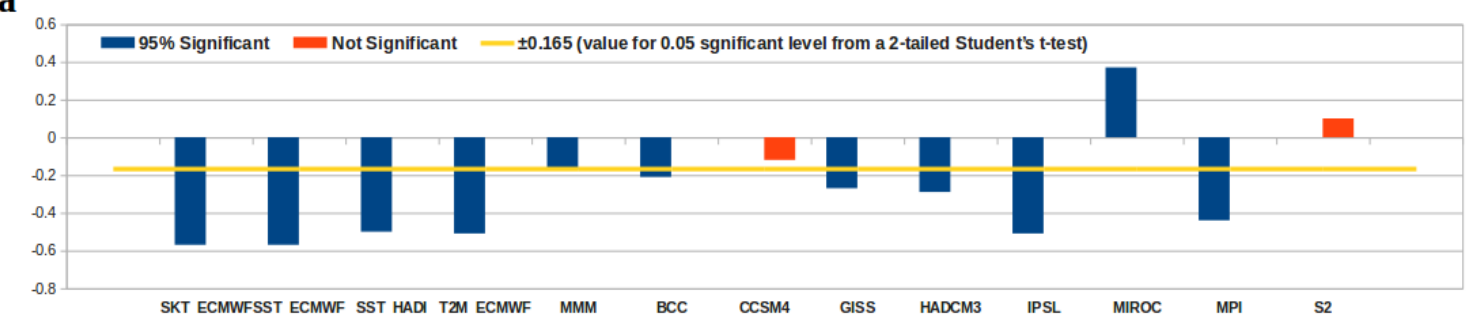

b

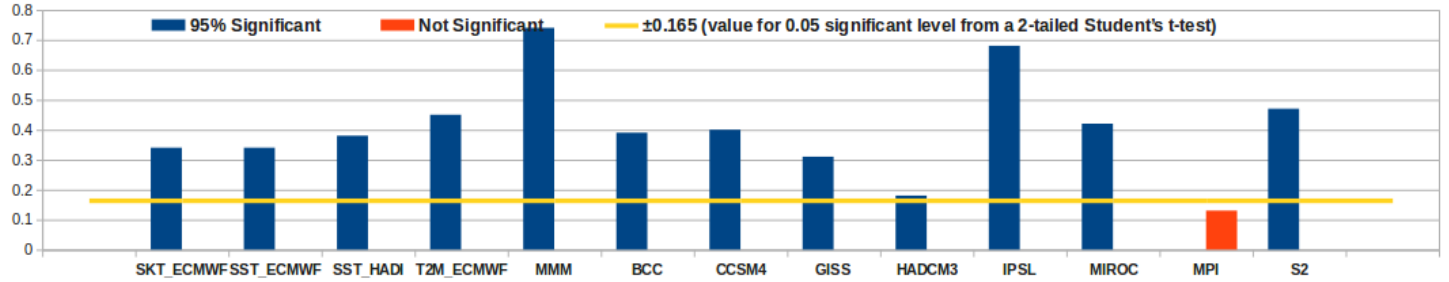

Figure 3:- Correlations with historical data between NINO3.4 and (a) ISMR (b) near surface air temperature over India. (Yellow line shows the significant value at 0.10 significant level from a 2-tailed Student's t-test, Blue (Red) colour bars show the significant (insignificant) values.

Table 2:- Interannual standard deviation of observational data and historical simulations of CMIP5 models.

\begin{tabular}{|l|l|l|l|l|l|}
\hline \multirow{2}{*}{ S No } & Models/Observations & \multicolumn{4}{|c|}{ Variables } \\
\cline { 3 - 6 } & & $\begin{array}{l}\text { Near air surface temperature } \\
\text { over Globe }\left({ }^{\circ} \mathrm{C}\right)\end{array}$ & $\begin{array}{l}\text { Near air surface temperature } \\
\text { over India }\left({ }^{\circ} \mathrm{C}\right)\end{array}$ & $\begin{array}{l}\text { NINO3.4 Index } \\
\left({ }^{\circ} \mathrm{C}\right)\end{array}$ & $\begin{array}{l}\text { Indian summer monsoon } \\
\text { rainfall (mm/day) }\end{array}$ \\
\hline 1 & SKT_ECMWF & 0.27 & 0.41 & 0.69 & 0.69 (RF_IMD) \\
\hline 2 & T2M_ECMWF & 0.29 & 0.39 & 0.45 & 0.53 (PRECIP_NOAA) \\
\hline 3 & SST_HADI & NA & NA & 0.60 & NA \\
\hline 4 & SST_ECMWF & NA & NA & 0.70 & NA \\
\hline 5 & MMM & 0.30 & 0.29 & 0.37 & 0.26 \\
\hline 6 & BCC & 0.33 & 036 & 0.76 & 0.77 \\
\hline 7 & CCSM4 & 0.35 & 0.43 & 0.80 & 0.60 \\
\hline 8 & GISS & 0.20 & 0.34 & 0.52 & 0.68 \\
\hline 9 & HADCM3 & 0.22 & 0.52 & 0.71 & 0.82 \\
\hline 10 & IPSL & 0.36 & 0.47 & 0.71 & 0.59 \\
\hline 11 & MIROC & 0.27 & 0.41 & 0.43 & 0.56 \\
\hline 12 & MPI & 0.26 & 0.48 & 0.74 & 0.57 \\
\hline 13 & S2 & 0.49 & 0.44 & 1.19 & 0.83 \\
\hline
\end{tabular}

In summary, the BCC-CSM-1-1(m), IPSL-CM5A-LR, MPI-ESM-P, GISS-E2-R, CCSM4, HadCM3 and FGOALS-s2 models meet our criteria for their p1000 simulations to be used for further analysis to understand the LM variability. The MIROC-ESM model will not be considered because it fails on at least two counts - a significantly simulated relationship between the ISR and NINO3.4 that is actually opposite to the observed relationship, and (ii) a strong trend in surface air temperature that is not in agreement with other models, and substantially higher than that observed in proxies. 
Clim. Past Discuss., doi:10.5194/cp-2017-24, 2017

Manuscript under review for journal Clim. Past

Discussion started: 31 March 2017

(c) Author(s) 2017. CC-BY 3.0 License.

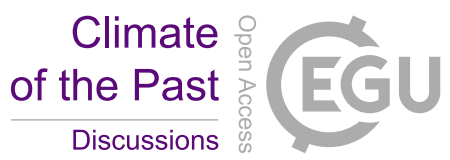

\section{2 p1000 analysis}

Figures $4 \mathrm{a}$ shows a 101-year running average of time series of globally-averaged simulated surface temperature for the JJAS season during LM i.e. from CE 850-1849, (henceforth $\mathrm{T}_{\mathrm{G}}$ ), and Figure $4 \mathrm{~b}$, the corresponding time series representing the surface temperature over the Indian sub-continent (henceforth $\mathrm{T}_{\mathrm{I}}$ ). The 101-year running window has been applied to identify the long term changes. The $\mathrm{T}_{\mathrm{G}}$ from the MMM ranges from $14.9^{\circ} \mathrm{C}$ to $14.7^{\circ} \mathrm{C}$, with higher temperature during the MWP and a slight cooling in the LIA. We note that the simulated signals in all the models evolve coherently in time, but with significant spread across the models.

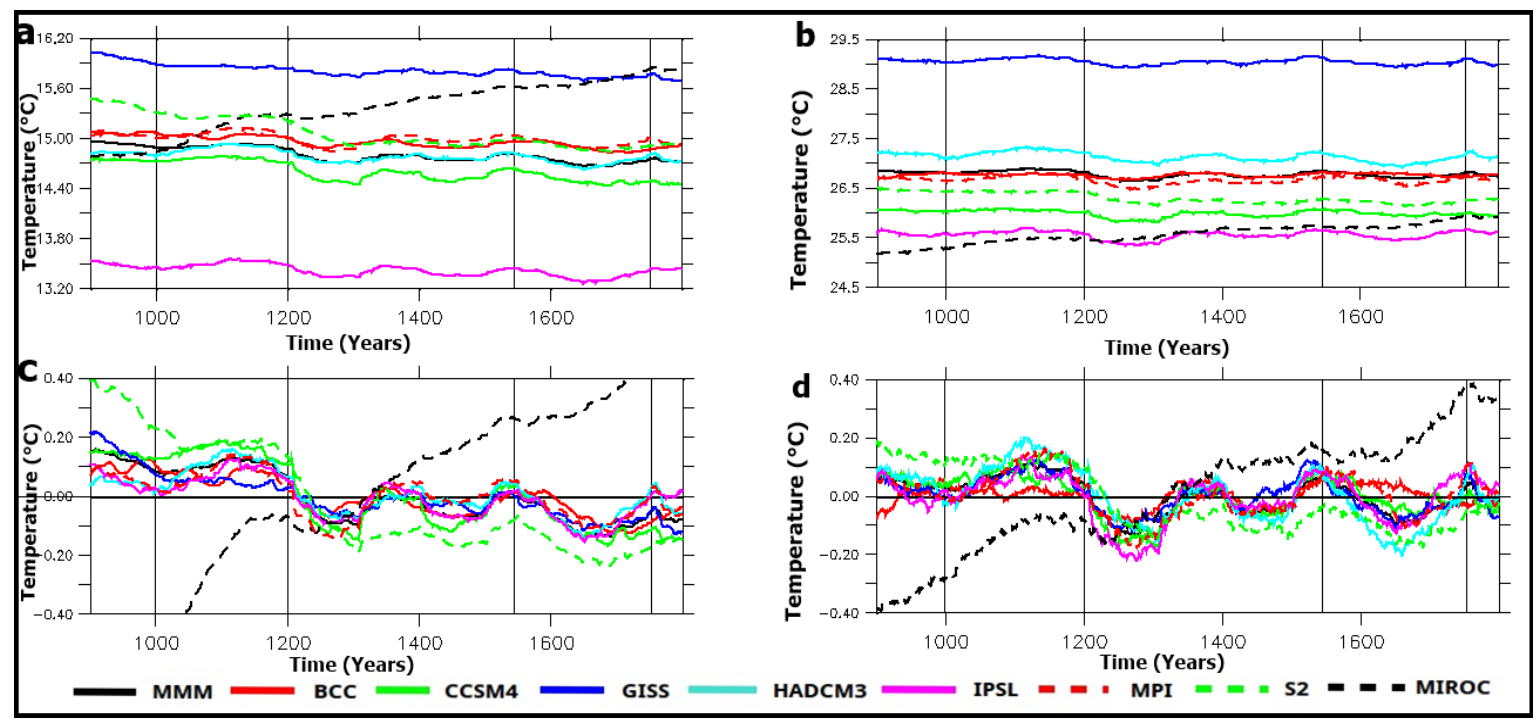

10

Figure 4:- 101-Year Running Mean of Near Air Surface Temperature $\left({ }^{0} \mathrm{C}\right)(\boldsymbol{a})$ Global (b) Indian Region. Corresponding anomalies (c) Global (d) Indian Region.

To tease out the signal more clearly, we calculated the 101-year running mean temporal anomalies

15 of the $T_{G}$, presented in Figure $4 \mathrm{c}$ and $\mathrm{T}_{\mathrm{I}}$ in Figure $4 \mathrm{~d}$. We see a relatively more coherent inter-model evolution in the anomalies as compared to the original data (Figure 4a). This indicates a bias in the mean climatology of two 'outlier' models. Omission of these model results removes such a bias. Indeed, it is a standard practice in seasonal prediction to give a multi-model prediction using the anomalies of temperature and rainfall, etc. rather than the original data so that the biases in the climatology do not mask

20 the coherent signals across the models (e.g. Min et al., 2009). Further, while there are fluctuations in temperature during LM, we see models showing a warming signal during the MWP (CE 1000-1199) and cooling during the LIA (CE 1550-1749), in general agreement with the observations durations (e.g. Box 
Clim. Past Discuss., doi:10.5194/cp-2017-24, 2017

Manuscript under review for journal Clim. Past

Discussion started: 31 March 2017

(c) Author(s) 2017. CC-BY 3.0 License.

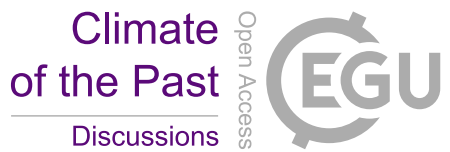

TS. 5 Figure 1b, Stocker et al, 2013 IPCC 2013; henceforth referred to as TS-IPCC13). The MWP is much more prominent if when we apply a 101-year running window on the time series (Figure 4c). Interestingly, in addition to these two well-known epochs, we see a few more climatic events, but with shorter duration. Prominent is a sharp cooling around CE 1250 seen across the models. Such a signal is apparent from a few proxy records as well (e.g. Fig. 1 of Box TS5, TS-IPCC13). Also evident is that all the modelled temperatures apparently enter a cooling phase from this point.

The spread in the time series of $T_{I}$ in different models (Figure $4 b$ ) is slightly less compared to that for the $\mathrm{T}_{\mathrm{G}}$ (Figure $4 \mathrm{a}$ ). The spread in the corresponding temporal anomalies across these models is less in magnitude as compared that for the anomalies of $\mathrm{T}_{\mathrm{G}}$ from various models. The warming (cooling) during the MWP (LIA) can be more prominently seen by applying a 101-year running mean to the temporal anomalies from each model (Figure $4 \mathrm{c}$ and 4d). The sharp cooling around CE 1250 seen in the global summer temperature across the models is simulated over the Indian region as well (Figures $4 \mathrm{c}$ and $4 \mathrm{~d}$ ).

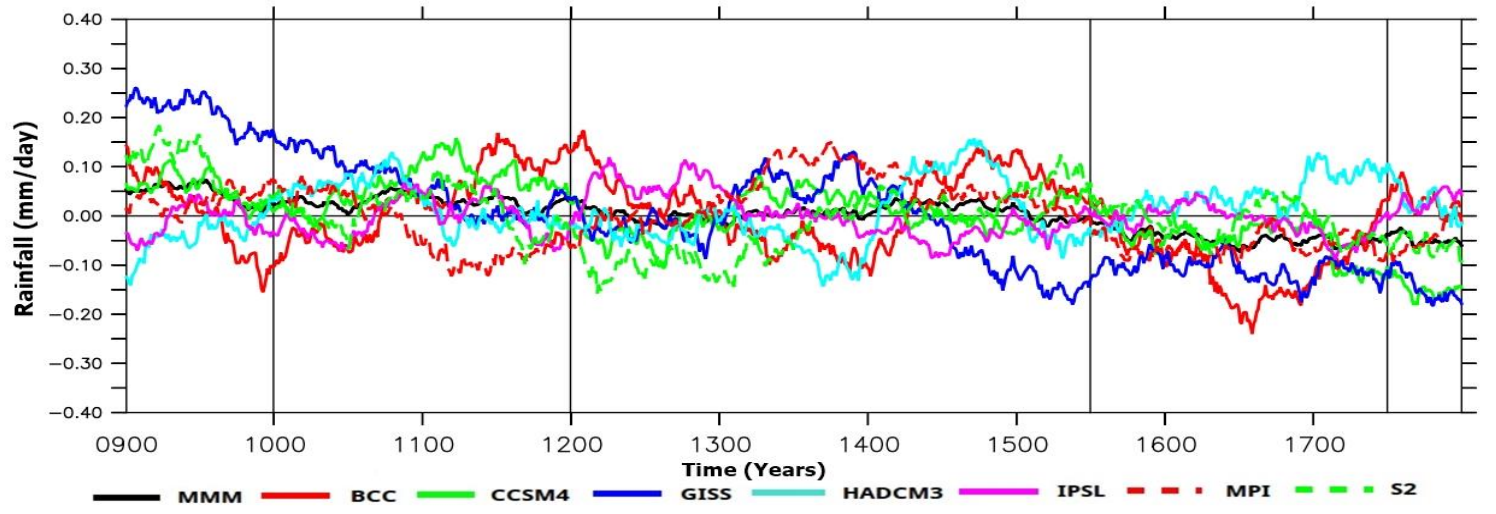

Figure 5:- Anomaly of 101-year Running mean of ISMR ( $\mathrm{mm} /$ day).

The 101-year running averages of the simulated ISMR anomaly, area-averaged over $65^{\circ} \mathrm{E}-95^{\circ} \mathrm{E}$ to $10^{\circ} \mathrm{N}-30^{\circ} \mathrm{N}$ (Figures 5), show a weak decreasing trend throughout the LM, in agreement with findings from several proxy records (e.g. Figure 8 of Ramesh et al., 2011). Having said this, Figure 5 also shows an intermodel spread in the anomalous evolution of the ISMR through the MWP. That is why, while the multimodel mean ISMR anomaly during the MWP shows a dip in the rainfall, the MMM anomaly does not actually become negative for this period (Figures 5), as would be expected from the concurrent above normal temperatures simulated over the Indian region (Figure 4b) by all the models as well as the MMM. As it is, the spread in the simulated IMSR rainfall across the models is a known general limitation of the 25 models (e.g. Jourdain et al., 2013). All this suggests a better agreement among the models in simulating the long term trend in rainfall over India relative to the variability during the MWP and that during the LIA. 
Clim. Past Discuss., doi:10.5194/cp-2017-24, 2017

Manuscript under review for journal Clim. Past

Discussion started: 31 March 2017

(c) Author(s) 2017. CC-BY 3.0 License.

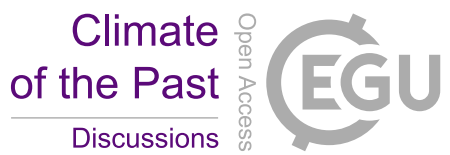

In comparison, as seen in Figures $4 \mathrm{~b}$ and $4 \mathrm{~d}$, the simulated temperature response over India during the MWP and LIA is relatively more coherent across the models, and its evolution qualitatively agrees with the few proxy records available.

We show the simulated correlation coefficients between $\mathrm{T}_{\mathrm{I}}$ and NINO3.4 index for the LM period (Table 3a). We also show, in Table 3a, similar correlations over the first, middle and the last 500 year periods of the LM. Similar correlations between the area-averaged ISMR and NINO3.4 index are presented in the Table 3b. Most of the correlations are significant at less than 0.05 level from a 2-tailed Student's ttest, suggesting that ENSO has been consistently influencing the Indian climate throughout the LM. In the

10 background of results from the multi-century model studies by Whittenberg et al. (2008 or 2009), which show a multi-decadal changes in the ENSO statistics, the consistent ENSO-monsoon links over a 100-year simulation across many models reconfirms that the ENSO is indeed a strong driver of the Indian summer monsoon climate variability.

\begin{tabular}{|c|c|c|c|c|c|}
\hline S No & Models & CE 0850-1849 & CE 0850-1349 & CE 1100-1599 & CE $1350-1849$ \\
\hline 1 & MMM & 0.49 & 0.53 & 0.52 & 0.44 \\
\hline 2 & $\mathrm{BCC}$ & 0.26 & 0.29 & 0.23 & 0.23 \\
\hline 3 & CCSM4 & 0.31 & 0.36 & 0.39 & 0.26 \\
\hline 4 & GISS & 0.38 & 0.31 & 0.38 & 0.43 \\
\hline 5 & HADCM3 & 0.30 & 0.31 & 0.30 & 0.28 \\
\hline 6 & IPSL & 0.59 & 0.61 & 0.58 & 0.58 \\
\hline 7 & MPI & 0.47 & 0.48 & 0.49 & 0.47 \\
\hline 8 & S2 & 0.41 & 0.44 & 0.37 & 0.35 \\
\hline
\end{tabular}

15

\begin{tabular}{|c|c|c|c|c|c|}
\hline S No & Models & CE 0850-1849 & CE 0850-1349 & CE $1100-1599$ & CE $1350-1849$ \\
\hline 1 & MMM & -0.15 & -0.12 & -0.17 & -0.21 \\
\hline 2 & $\mathrm{BCC}$ & -0.32 & -0.34 & -0.30 & -0.29 \\
\hline 3 & CCSM4 & -0.12 & -0.08 & -0.11 & -0.17 \\
\hline 4 & GISS & -0.28 & -0.24 & -0.33 & -0.34 \\
\hline 5 & HADCM3 & -0.39 & -0.37 & -0.37 & -0.40 \\
\hline 6 & IPSL & -0.70 & -0.74 & -0.69 & -0.66 \\
\hline 7 & MPI & -0.43 & -0.43 & -0.46 & -0.44 \\
\hline 8 & S2 & -0.05 & -0.07 & -0.05 & -0.03 \\
\hline
\end{tabular}

To verify that there is a reasonable agreement of variability among the individual models, we present in Table 4 the JJAS standard deviations $(\sigma)$ of the simulated area-averaged global rainfall, areaaveraged surface temperature, and the NINO3.4 index for the whole period as well as three overlapping 
Clim. Past Discuss., doi:10.5194/cp-2017-24, 2017

Manuscript under review for journal Clim. Past

Discussion started: 31 March 2017

(c) Author(s) 2017. CC-BY 3.0 License.

500-year sub-periods, namely, CE 850-1349, CE1100-1599, and CE 1350-1849. The simulated statistics from the individual models fall within the $\pm 1 \sigma$ range of the corresponding statistic from the MMM (Table 4) in general, except the $\sigma$ of the simulated NINO3.4 index from the S2 model. This shows that the simulated variabilities across the models are, in general, in reasonable agreement with one another.

Table 4:- Boreal summer interannual standard deviation of near air surface temperature and ISMR, as simulated by CMIP5/PMIP3 Last Millennium models (here A: CE 0850-1849; B:CE 0850-1349; C: CE 1100-1599 and D: CE 1350-1849)

\begin{tabular}{|c|c|c|c|c|c|c|c|c|c|c|c|c|c|c|c|c|c|}
\hline \multirow[t]{3}{*}{ S No } & \multirow[t]{3}{*}{ Models } & \multicolumn{16}{|c|}{ Variables } \\
\hline & & \multicolumn{4}{|c|}{$\begin{array}{l}\text { Near air surface } \\
\text { temperature over } \\
\text { Globe }\left({ }^{\circ} \mathrm{C}\right)\end{array}$} & \multicolumn{4}{|c|}{$\begin{array}{l}\text { Near air surface } \\
\text { temperature India }\left({ }^{\circ} \mathrm{C}\right)\end{array}$} & \multicolumn{4}{|c|}{$\begin{array}{l}\text { Indian summer monsoon } \\
\text { rainfall }(\mathrm{mm} / \text { day })\end{array}$} & \multicolumn{4}{|c|}{ NINO3.4 Index $\left({ }^{\circ} \mathrm{C}\right)$} \\
\hline & & A & B & $\mathrm{C}$ & $\mathrm{D}$ & A & $\mathrm{B}$ & $\mathrm{C}$ & $\mathrm{D}$ & A & $\mathrm{B}$ & $\mathrm{C}$ & $\mathrm{D}$ & A & $\mathrm{B}$ & $\mathrm{C}$ & $\mathrm{D}$ \\
\hline 1 & MMM & 0.15 & 0.15 & 0.15 & 0.13 & 0.20 & 0.20 & 0.22 & 0.19 & 0.26 & 0.25 & 0.26 & 0.27 & 0.29 & 0.30 & 0.30 & 0.28 \\
\hline 2 & BCC & 0.13 & 0.13 & 0.13 & 0.11 & 0.29 & 0.30 & 0.29 & 0.28 & 0.76 & 0.74 & 0.75 & 0.77 & 0.65 & 0.65 & 0.64 & 0.65 \\
\hline 3 & CCSM4 & 0.25 & 0.25 & 0.27 & 0.21 & 0.38 & 0.40 & 0.40 & 0.37 & 0.62 & 0.59 & 0.60 & 0.64 & 0.73 & 0.75 & 0.74 & 0.72 \\
\hline 4 & GISS & 0.19 & 0.18 & 0.16 & 0.18 & 0.35 & 0.33 & 0.35 & 0.36 & 0.70 & 0.70 & 0.71 & 0.69 & 0.45 & 0.43 & 0.45 & 0.46 \\
\hline 5 & HADCM3 & 0.20 & 0.19 & 0.19 & 0.20 & 0.46 & 0.33 & 0.46 & 0.49 & 0.76 & 0.73 & 0.74 & 0.78 & 0.63 & 0.60 & 0.62 & 0.60 \\
\hline 6 & IPSL & 0.19 & 0.20 & 0.20 & 0.18 & 0.39 & 0.41 & 0.41 & 0.37 & 0.54 & 0.55 & 0.56 & 0.53 & 0.60 & 0.60 & 062 & 0.60 \\
\hline 7 & MPI & 0.20 & 0.20 & 0.21 & 0.20 & 0.42 & 0.41 & 0.44 & 0.42 & 0.60 & 0.61 & 0.60 & 0.69 & 0.59 & 0.60 & 0.63 & 0.58 \\
\hline 8 & S2 & 0.26 & 0.25 & 0.21 & 0.18 & 0.39 & 0.40 & 0.40 & 0.36 & 0.75 & 0.76 & 0.76 & 0.74 & 1.14 & 1.15 & 1.15 & 1.11 \\
\hline
\end{tabular}

\subsection{MWP and LIA Analysis}

From Figure 4, we surmise that Indian Sub-continent was warmer (relatively cooler) during the CE 1000-1199 (CE 1550-1749) than the many other regions of the globe, which is reasonable from the context of its tropical and subtropical location. The simulated summer temperature during the MWP over India was higher than the corresponding global temperatures. The multi-model mean global temperature anomaly varies between $0.6^{\circ} \mathrm{C}$ and $-1.5^{\circ} \mathrm{C}$ during the $\mathrm{LM}$.

Simultaneous correlation coefficients between the summer NINO3.4 index with the ISMR and during the MWP and LIA from the individual models and the MMM are shown in Figure 6a, and those with the ISM surface temperature are shown in the Figure 6b. All these values are also realistic as well as statistically significant at 0.1 level. Note that the significance of ISMR-NINO34 index correlations from GOALS-s2 for both MWP and LIA periods and those from MMM for the LIA, the correlations are above

200.05 level. The correlation of the NINO3.4 index with the ISMR \& that with the Indian surface temperature from the MMM stand, respectively, at -0.19 and 0.31 for the MWP and -0.09 and 0.36 during the LIA. The signs of the correlations are in agreement with those for the current period. Thus, for the Indian region, the magnitudes of the correlations with the ENSO index are stronger in the case of the surface temperature as compared to the rainfall. Interestingly, in five models out of the seven and the MMM, the magnitudes of

25 the correlation coefficients of the NINO3.4 index with the ISMR, and those of the NINO3.4 index correlations with the JJAS surface temperature over India are weaker in the LIA relative to the MWP. 
Understandably, the corresponding results from the MMM also show stronger relationships of the Indian summer climate with the ENSO during the MWP as compared to the LIA (Figure 6). These correlations show a strong multi-decadal-through-centennial modulation between the ENSO and ISM during LM. More importantly, these results suggest that any long term weakening between the ENSO-Indian summer monsoon (e.g. Kumar et al., 1999; Ashok et al., 2001) is not necessarily due to anthropogenic climate change.

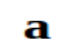

a

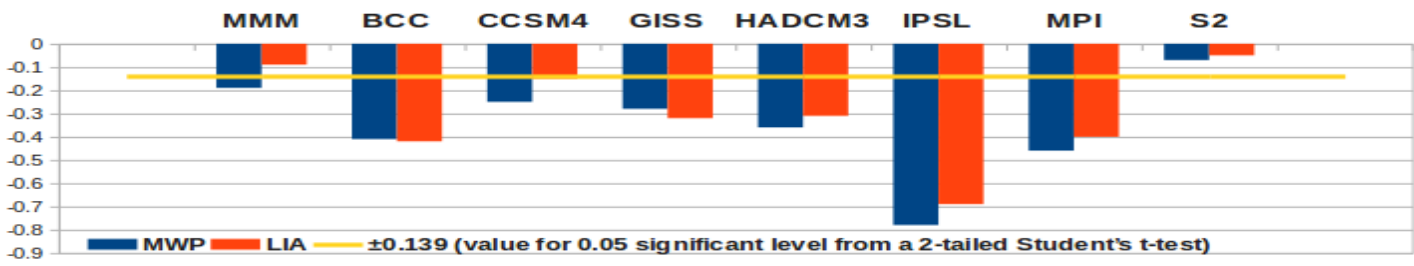

$\mathbf{b}$

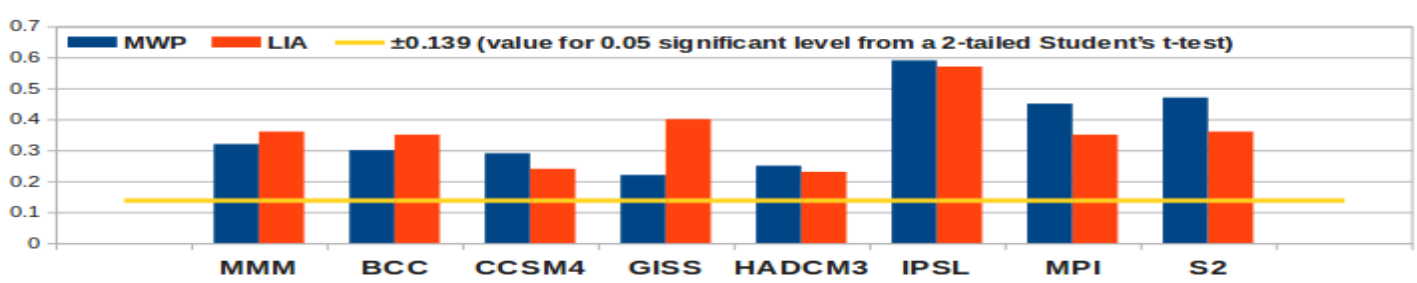

Figure 6:- Correlations during MWP and LIA (JJAS), between (a) NINO3.4 and ISMR (b) NINO3.4 and Near Air Surface Temperature. (Yellow line shows the significant value at 0.05 level from a 2-tailed Student's t-test)

To explore further, we present the time series of the NINO3.4 index from the MMM of Figure 7. We present the simulated frequencies El Niños and La Niñas during the MWP and LIA by the individual models in Table 5. To calculate the frequency of the El Niño and La Niña events, we define a criterion

15 shown in Table 6. We see from Figure 7 that all models and the MMM, except the BCC model, consistently simulate more El Niños as compared to La Niñas (including Moderate and Strong events) during the MWP compared to the LIA; this result is statistically significant at 0.05 level from a 2-tailed Student's t-test carried out for difference of means (M1 is Average of the simulated frequency of the MWP El Niño events by each of the seven models and M2 is average of the simulated frequency of the LIA El

20 Niño events by each of the seven models). However, the BCC model simulates relatively more number of El Niños during the LIA. It is known that the El Niños (La Niñas) cause anomalous increase (decrease) in global temperature. Therefore, a predominant presence of higher number of simulated El Niños as compared to La Niñas in almost all the models is the reason why the simulated MWP is warmer as compared to the LIA. Given this agreement across the models, we can surmise that, in real world too, the

25 MWP is likely due to the occurrence of a relatively higher frequency of El Niños as compared to the La Niñas. 
Clim. Past Discuss., doi:10.5194/cp-2017-24, 2017

Climate

Manuscript under review for journal Clim. Past

Discussion started: 31 March 2017

(c) Author(s) 2017. CC-BY 3.0 License.

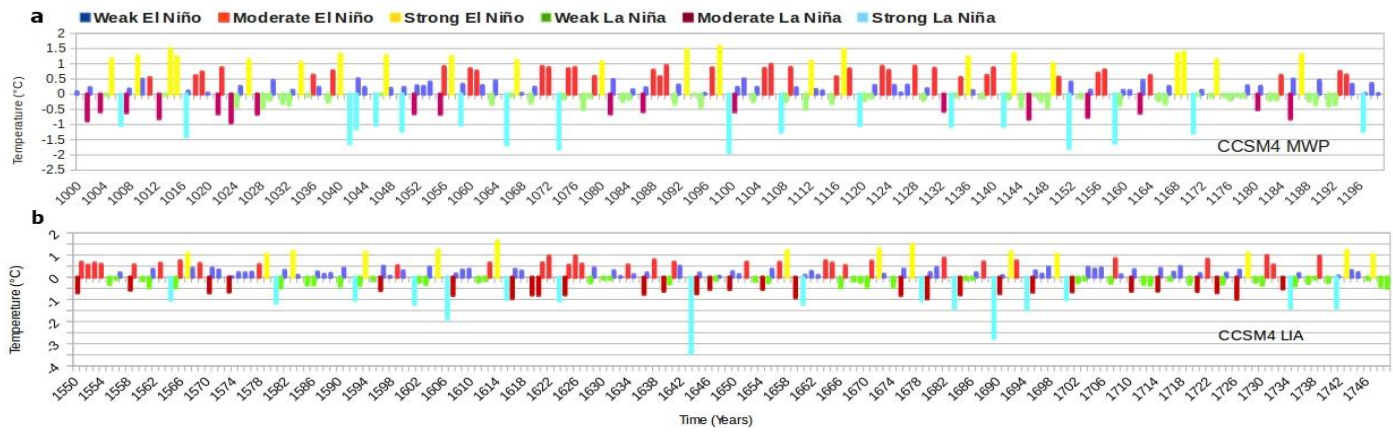

Figure 7 NINO3.4 $\left({ }^{\circ}\right.$ C) Index of CCSM4 during (a) MWP, (b) LIA.

Further, there is a discrepancy across the models in the El Niño, La Niña frequencies for the LIA.

5 This may be a factor that why the magnitude of the NINO3.4-ISMR correlations are relatively weaker during the LIA.

Table-5 El Niño and La Niña Classification

\begin{tabular}{|l|l|l|l|l|}
\hline $\begin{array}{l}\text { S. } \\
\text { No }\end{array}$ & \multicolumn{2}{|l|}{ El Niño Classification } & \multicolumn{2}{l|}{ La Niña Classification } \\
\hline 1 & $0^{\circ} \mathrm{C}<0.5^{\circ} \mathrm{C}$ & Weak El Niño & $-0.5^{\circ} \mathrm{C}<0^{\circ} \mathrm{C}$ & Weak La Niña \\
\hline 2 & $0.5^{\circ} \mathrm{C}<1.0^{\circ} \mathrm{C}$ & Moderate El Niño & $-1.0^{\circ} \mathrm{C}<-0.5^{\circ} \mathrm{C}$ & Moderate La Niña \\
\hline 3 & $>1.0^{\circ} \mathrm{C}$ & Strong El Niño & $<-1.0^{\circ} \mathrm{C}$ & Strong La Niña \\
\hline
\end{tabular}

Table 6:- Frequency table of simulated El Niños and La Niñas during MWP (CE 1000-1199) and LIA (CE 1550-1749) of CMIP5/PMIP3 models.

\begin{tabular}{|c|c|c|c|c|c|c|c|c|c|c|c|c|c|}
\hline \multirow[t]{2}{*}{ S No } & \multirow[t]{2}{*}{ Models } & \multicolumn{6}{|c|}{ MWP (CE 1000-1199) } & \multicolumn{6}{|c|}{ LIA (CE 1550-1749) } \\
\hline & & $\begin{array}{l}\text { Weak El } \\
\text { Niños }\left(0^{\circ} \text { - }\right. \\
\mathrm{C}< \\
\left.0.5^{\circ} \mathrm{C}\right)\end{array}$ & $\begin{array}{l}\text { Moderate } \\
\text { El Niños } \\
\left(0.5^{\circ} \mathrm{C}<\right. \\
\left.1.0^{\circ} \mathrm{C}\right)\end{array}$ & \begin{tabular}{|l|} 
Strong El \\
Niños \\
$\left(1.0^{\circ} \mathrm{C}\right)$
\end{tabular} & $\begin{array}{l}\text { Weak La } \\
\text { Niñas } \\
\left(-0.5^{\circ} \mathrm{C}<\right. \\
\left.0^{\circ} \mathrm{C}\right) \\
\end{array}$ & $\begin{array}{l}\text { Moderate } \\
\text { La Niñas } \\
\left(-1.0^{\circ} \mathrm{C}<-\right. \\
\left.0.5^{\circ} \mathrm{C}\right) \\
\end{array}$ & $\begin{array}{l}\text { Strong } \\
\text { La Niñas } \\
(< \\
\left.1.0^{\circ} \mathrm{C}\right) \\
\end{array}$ & $\begin{array}{l}\text { Weak El } \\
\text { Niños }\left(0^{\circ}-\right. \\
\left.\mathrm{C}<0.5^{\circ} \mathrm{C}\right)\end{array}$ & $\begin{array}{l}\text { Moderate } \\
\text { El Niños } \\
\left(0.5^{\circ} \mathrm{C}<\right. \\
\left.1.0^{\circ} \mathrm{C}\right) \\
\end{array}$ & $\begin{array}{l}\text { Strong El } \\
\text { Niños } \\
\left(1.0^{\circ} \mathrm{C}\right)\end{array}$ & $\begin{array}{l}\text { Weak La } \\
\text { Niñas } \\
\left(-0.5^{\circ} \mathrm{C}<\right. \\
\left.0^{\circ} \mathrm{C}\right) \\
\end{array}$ & $\begin{array}{l}\text { Moderate } \\
\text { La Niñas } \\
\left(-1.0^{\circ} \mathrm{C}<-\right. \\
\left.0.5^{\circ} \mathrm{C}\right)\end{array}$ & $\begin{array}{l}\text { Strong } \\
\text { La Niñas } \\
\left(<1.0^{\circ} \mathrm{C}\right) \\
\end{array}$ \\
\hline 1 & MMM & 111 & 10 & 0 & 82 & 2 & 0 & 76 & 2 & 0 & 110 & 6 & 0 \\
\hline 2 & BCC & 56 & 53 & 7 & 63 & 36 & 9 & 38 & 27 & 19 & 48 & 28 & 16 \\
\hline 3 & CCSM4 & 54 & 37 & 22 & 61 & 33 & 14 & 51 & 18 & 18 & 46 & 28 & 16 \\
\hline 4 & GISS & 77 & 29 & 0 & 79 & 21 & 0 & 73 & 19 & 2 & 69 & 28 & 3 \\
\hline 5 & HADCM3 & 63 & 40 & 12 & 64 & 16 & 12 & 57 & 24 & 4 & 64 & 24 & 20 \\
\hline 6 & IPSL & 65 & 34 & 22 & 63 & 23 & 10 & 52 & 26 & 12 & 60 & 35 & 9 \\
\hline 7 & MPI & 60 & 34 & 15 & 55 & 26 & 7 & 61 & 24 & 6 & 72 & 33 & 7 \\
\hline 8 & S2 & 33 & 21 & 53 & 32 & 25 & 29 & 19 & 28 & 36 & 33 & 41 & 40 \\
\hline
\end{tabular}

10

The simulated interannual standard deviation of JJAS surface temperatures (for both global as well as the Indian regions), the ISMR and the NINO3.4 index during the MWP and LIA periods are presented in Table 7. From this table, it is evident that the standard deviations do not apparently change much across the LM. The simulated LIA standard deviations, however, are in general moderately stronger in amplitude than those for the MWP. 
Clim. Past Discuss., doi:10.5194/cp-2017-24, 2017

Manuscript under review for journal Clim. Past

Discussion started: 31 March 2017

(c) Author(s) 2017. CC-BY 3.0 License.

Table 7:- Boreal summer simulated interannual standard deviation during MWP (CE 1000-11199) and LIA (CE 1550-1749) of CMIP5/PMIP3 models.

\begin{tabular}{|c|c|c|c|c|c|c|c|c|c|}
\hline \multirow[t]{3}{*}{ S No } & \multirow[t]{3}{*}{ Models } & \multicolumn{8}{|c|}{$\begin{aligned} \text { Variables } \\
\end{aligned}$} \\
\hline & & \multicolumn{2}{|c|}{$\begin{array}{l}\text { Near air surface } \\
\text { temperature over Globe } \\
\left({ }^{\circ} \mathrm{C}\right)\end{array}$} & \multicolumn{2}{|c|}{$\begin{array}{l}\text { Near air surface temperature } \\
\text { over India }\left({ }^{\circ} \mathrm{C}\right)\end{array}$} & \multicolumn{2}{|c|}{$\begin{array}{l}\text { Indian summer monsoon } \\
\text { rainfall (mm/day) }\end{array}$} & \multicolumn{2}{|c|}{ NINO3.4 Index $\left({ }^{\circ} \mathrm{C}\right)$} \\
\hline & & MWP & LIA & MWP & LIA & MWP & LIA & MWP & LIA \\
\hline 1 & MMM & 0.06 & 0.11 & 0.13 & 0.16 & 0.25 & 0.26 & 0.26 & 0.26 \\
\hline 2 & BCC & 0.11 & 0.13 & 0.28 & 0.29 & 0.76 & 0.82 & 0.70 & 0.64 \\
\hline 3 & CCSM4 & 0.13 & 0.17 & 0.33 & 0.32 & 0.53 & 0.60 & 0.73 & 0.72 \\
\hline 4 & GISS & 0.09 & 0.17 & 0.29 & 0.34 & 0.69 & 0.67 & 0.42 & 0.42 \\
\hline 5 & HADCM3 & 0.15 & 0.18 & 0.39 & 0.44 & 0.73 & 0.76 & 0.58 & 0.65 \\
\hline 6 & IPSL & 0.17 & 0.17 & 0.37 & 0.36 & 0.56 & 0.51 & 0.61 & 0.58 \\
\hline 7 & MPI & 0.13 & 0.17 & 0.37 & 0.40 & 0.67 & 0.60 & 0.58 & 0.58 \\
\hline 8 & S2 & 0.13 & 0.15 & 0.37 & 0.36 & 0.75 & 0.71 & 1.14 & 1.07 \\
\hline
\end{tabular}

\subsection{Possible Dynamics involved - a preliminary analysis}

Carrying out a detailed analysis of the background dynamics is beyond the scope of the current manuscript. However, we present results from a preliminary analysis from various models in Figure 8 to delineate, if possible, a common view of the dynamics behind the higher (lesser) rainfall during the MWP (LIA) over India relative to the long term mean. Note that, as far as the Figure 8 is concerned, 'anomalies'

10 for any parameter during the MWP (LIA) refer to the excess of the said parameter during the MWP (or LIA) as compared to that over the LM (i.e. $\mathrm{P}_{\mathrm{MWP}}-\mathrm{P}_{\mathrm{LIA}}$, for example, $\mathrm{P}$ being any parameter averaged over the respective period). From the distribution of boreal summer velocity potential at $850 \mathrm{hPa}$ simulated by CCSM4, for example, (Figure 8a) in the central tropical pacific, we see a zone of anomalous convergence in the central tropical pacific, flanked by two zones of divergence in the equatorial pacific, suggesting a

15 westward shift in Walker circulation (e.g. Vechchi et al., 2006) as compared to the current day signal. While this may suggest only a background change, this also may be partly due to due to the more number of El Niños as compared to La Niñas (Table 5) during the MWP as compared to the LM, the signature of the predominant interannual skewness in the ENSO frequency that manifests as a background change (e.g. Fedorov and Philander, 2000). The anomalous divergence centre in the west also extends into the equatorial eastern Indian Ocean, which results in an anomalous convergence zone over India (Figure 8d), and therefore excess rainfall during the MWP (Figure 8c) as compared to the LM. The corresponding results from the MMM and other models (Figure A1) are qualitatively similar to those shown in Figure 8. 
Clim. Past Discuss., doi:10.5194/cp-2017-24, 2017

Manuscript under review for journal Clim. Past

Discussion started: 31 March 2017

(c) Author(s) 2017. CC-BY 3.0 License.
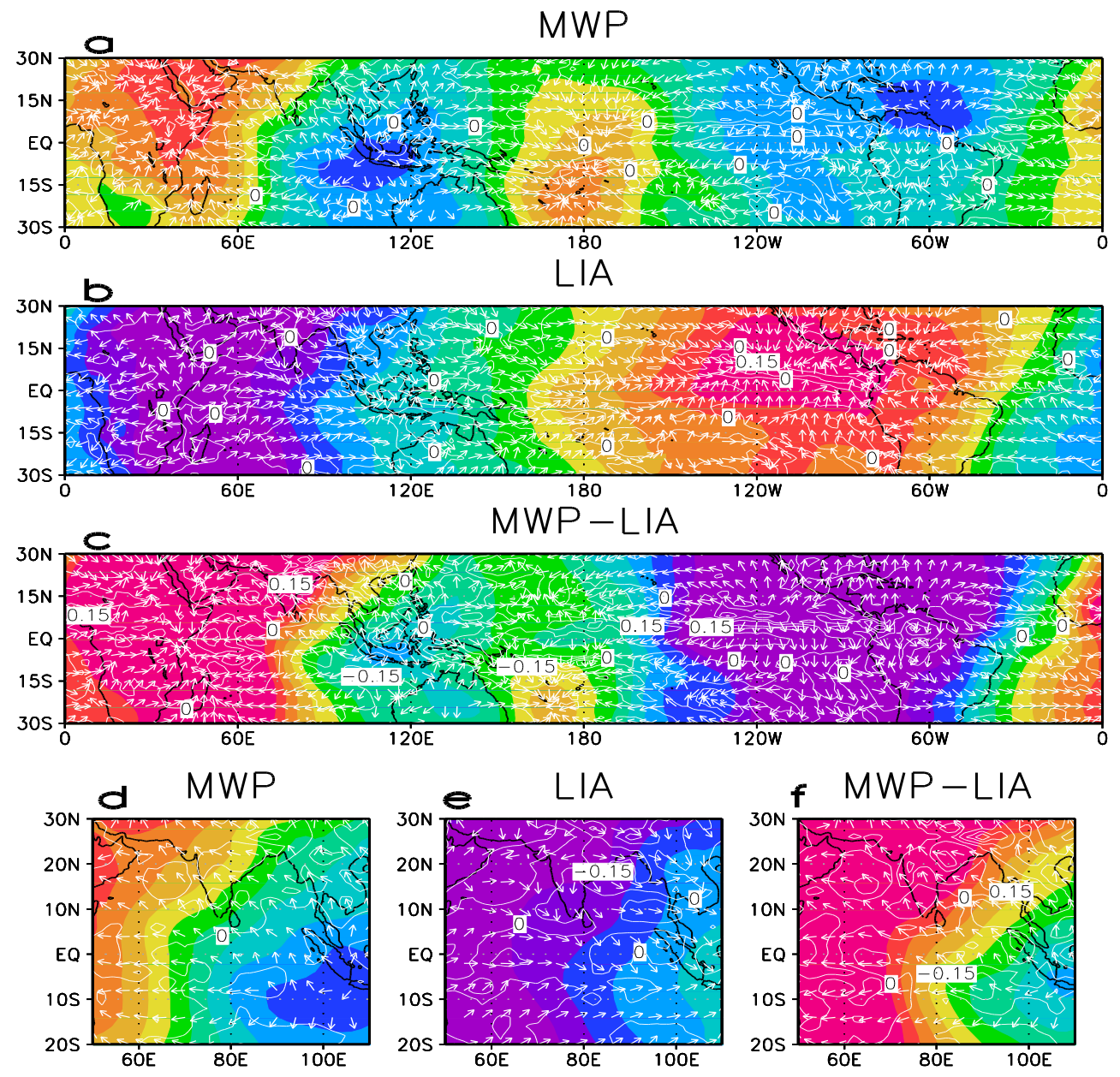

$$
\begin{array}{llllllll}
-0.1-0.08-0.06-0.04-0.02 & 0 & 0.02 & 0.04 & 0.06 & 0.08 & 0.1
\end{array}
$$

Figure 8 Anomalous fields of JJAS rainfall ( $\mathrm{mm} /$ day; contours) $850 \mathrm{hPa}$ divergent winds $\left(\mathrm{ms}^{-1}\right)$ and velocity potential $\left(\mathrm{m}^{2} \mathrm{~s}^{-1}\right.$; Shaded) from the CCSM4 (a) during MWP, (b) during LIA, and (c) the respective differences between the MWP \& LIA (MWP-LIA). Figures $(\boldsymbol{d}),(\boldsymbol{e}) \&(f)$ are same as Figures $8(\boldsymbol{a}),(\boldsymbol{b})$ and $(c)$, respectively, except that they are zoomed into the Indian \& tropical Indian Ocean regions.

We must mention that composited the spatial distribution of rainfall anomalies shown in Figure 9 is not statistically significant (2-tailed Student's t-test for precipitation of each model over Indian domain at significant level of 0.10 carried out and they are shown at A2). This is because, in addition to CCSM4 and

10 four other models, namely GISS, IPSL, HADCM3, S2, show an anomalous excess in rainfall, and the locations of rainfall surplus in these individual models over India are not co-located across the models (Figures A3). However, as a majority of models indicates a similar sign, the results can be accepted qualitatively. We also see a modest warming across the region, in agreement with Figure $4 \mathrm{~d}$. The 
distribution of temperature anomalies, and their phase, also differs across the models (Figure A3). On the other hand, during the LIA, the background convergence/divergence anomalies (Figure $8 \mathrm{~b}$ ) suggest a relatively stronger convergence in the eastern tropical pacific, possibly due to more number of La Niñas. Interestingly, we also see an anomalous convergence in the equatorial Indian Ocean, which apparently results in a divergence over India, and relatively lesser rainfall.
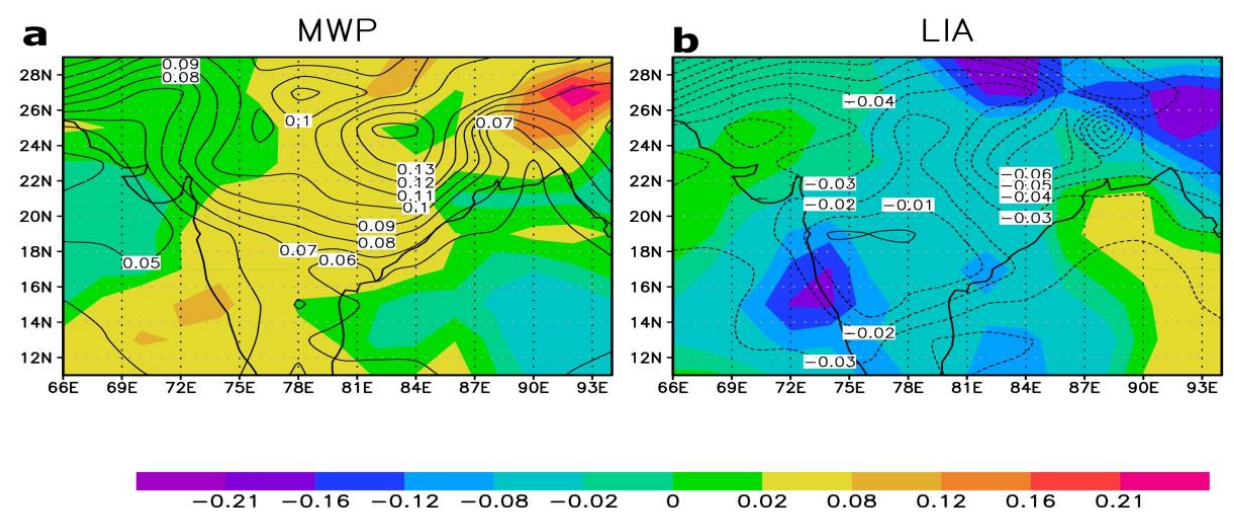

GrADS: COLA/IGES

2017-02-22-19:09

Figure 9 Anomalous fields of JJAS surface temperature $\left({ }^{\circ} \mathrm{C}\right)$ and rainfall (mm/day; shaded) zoomed over Indian region (a) during $M W P(\boldsymbol{b})$ during LIA.

\section{Conclusion}

The global climate has experienced significant centennial climate variations in the last two millennia, without any apparent commensurate changes in the external climate forcing (IPCC, 2013). Proxy-data based studies identify two significant events in the last millennium (LM): (i) a relatively warm period known in the literature as the 'Medieval Warm Period' (MWP, CE 950-1350) followed roughly after 150-200 years by (ii) a relatively cooler period referred to as the Little Ice Age (LIA, CE 1500-1850. Notably, variability of ISM is relatively less studied on centennial to millennial timescales. A few proxy records also document such periods in the Indian region, though there is uncertainty associated with the sparse observations.

To complement the proxy-studies, here we carried out an analysis on the PMIP3 data sets. Out of the available data sets from eight models, we chose datasets from seven models after due validation of the corresponding historical climate (CE 1901-2005) simulations over the Indian region. We find that the 
Clim. Past Discuss., doi:10.5194/cp-2017-24, 2017

Manuscript under review for journal Clim. Past

Discussion started: 31 March 2017

(c) Author(s) 2017. CC-BY 3.0 License.

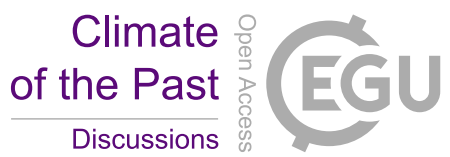

multi-model mean simulates the temperature trends during MWP and LIA epochs during CE 1000-1199 and CE 1550-1749, roughly commensurate with the proxy-observations. Our analysis of the PMIP3 data sets suggests that the Indian region was likely warmer than the global temperature during the MWP. The models also suggest a cooling signal in India during the LIA.

A majority of models qualitatively reproduce a wetter (drier) Indian summer monsoon season in the MWP (LIA) relative to the mean Indian summer monsoon during the LM. The models simulate a statistically significant ENSO-Monsoon association in the LM as observed in the current day climate. Interestingly, we find a multi-centennial modulation of the simulated ENSO-ISMR correlations. At least

10 four models suggest a decreasing ENSO-ISMR (as well as that with the Indian summer temperatures) correlation in the last 500-years of the LM as compared to the first 500-years of LM. Six out of seven models simulate more El Niños during MWP as compared to La Niñas. Notwithstanding such a propensity in El Niños relative to the LM a relatively westward shift during the MWP in comparison with the mean LM condition seen in the in the multi-model mean summer Walker circulation is associated an apparent

15 anomalous divergence in the equatorial eastern Indian Ocean, which in turns results in anomalous convergence and excess rainfall in the Indian region. Several model studies (e.g. Ashok et al. 2004) indicate that a presence of anomalous low level divergence in the eastern equatorial Indian Ocean is critical in causing an anomalous divergence over the peninsular Indian region and thereby leading to less than mean rainfall there. It is reasonable that the convergence/divergence patterns in the eastern equatorial

20 Indian Ocean, which is more of a peripheral region for ENSO impact, may change depending on the strength of the ENSO. We must be mindful, however, that the relatively higher precipitation over India is simulated only in five models, and the location of this excess precipitation is not same across these five models. The simulated spatial distribution of the multi-model average of surface temperature over India is only modestly higher as compared to the corresponding LM average, owing to the spread of the signals across the models. However, it is intriguing that that such a signal, however modest it is, is simulated in conjunction with rainfall that exceeds the corresponding LM-mean (Figure 9). This aspect is not an artefact of multi-model averaging (Figures from the individual models shown in A3), and needs further examination. A plausible reason is that the simulated Indian summer rainfall during the MWP mostly comes from more number of extreme rainfall events as compared to the LM-average, a situation somewhat analogous to warmer and wetter scenario due to the increased saturated water vapour associated with increased temperature in the background of global warming (e.g. Lehmann et al., 2015; Goswami et al., 2006). One also needs to be sensitive to the plausibility that at least some of the changes in the Indian climate during the LM may also be due to 'direct' impacts pf the changes in the radiative forcing through the LM, rather than just due to the 'internal' variability such as the changing ENSO characteristics. 
Clim. Past Discuss., doi:10.5194/cp-2017-24, 2017

Manuscript under review for journal Clim. Past

Discussion started: 31 March 2017

(c) Author(s) 2017. CC-BY 3.0 License.

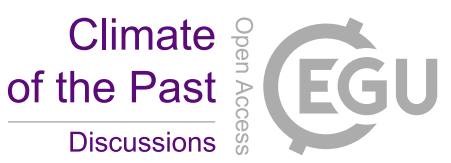

Further, eight out of eight (including MMM) models simulate more El Niños as compared to La Niñas in MWP and seven out of eight models simulate more La Niñas in LIA as compared to the El Niños. In these simulations, we see anomalous convergence in the tropical Indian Ocean during the LIA relative to the LM period, which results in anomalous divergence over the Indian region associated with less summer rainfall as compared to the corresponding LM mean value. The results of course are subject to the model uncertainties and inter-model spread. Having said this, a qualitative agreement across the models, and the agreement with the findings from available proxy data, gives us some confidence in the results. It will be interesting to examine the anomalous changes in the summer Walker circulation in the tropical Indian

10 ocean during the MWP \& LIA, which are apparently not only different from the typical ENSO signatures observed in the current day climate, but apparently result in signatures of the ENSO in ISMR that are opposite to the current day ENSOs. We plan to conduct a suite of atmospheric GCM experiments in addition to some specially designed coupled experiments in this connection. Another important relevant aspect that we hope to study is to explore whether the models are able to simulate the shrinking of the 'Indo-Pacific' rain belt during the LIA as documented by Denniston et al. (2016) from proxy-data sets, and if they do, whether such a shrinking has a role to play in the changed ENSO-Monsoon links, at least in the model world.

\section{Data Availability}

Model datasets have been downloaded and available from "http://cerawww.dkrz.de/WDCC/ui/Index.jsp"

\section{Acknowledgement} for his help. 
Clim. Past Discuss., doi:10.5194/cp-2017-24, 2017

Manuscript under review for journal Clim. Past

Discussion started: 31 March 2017

(c) Author(s) 2017. CC-BY 3.0 License.

Climate
of the Past

Discussions

\section{(c) (1)}

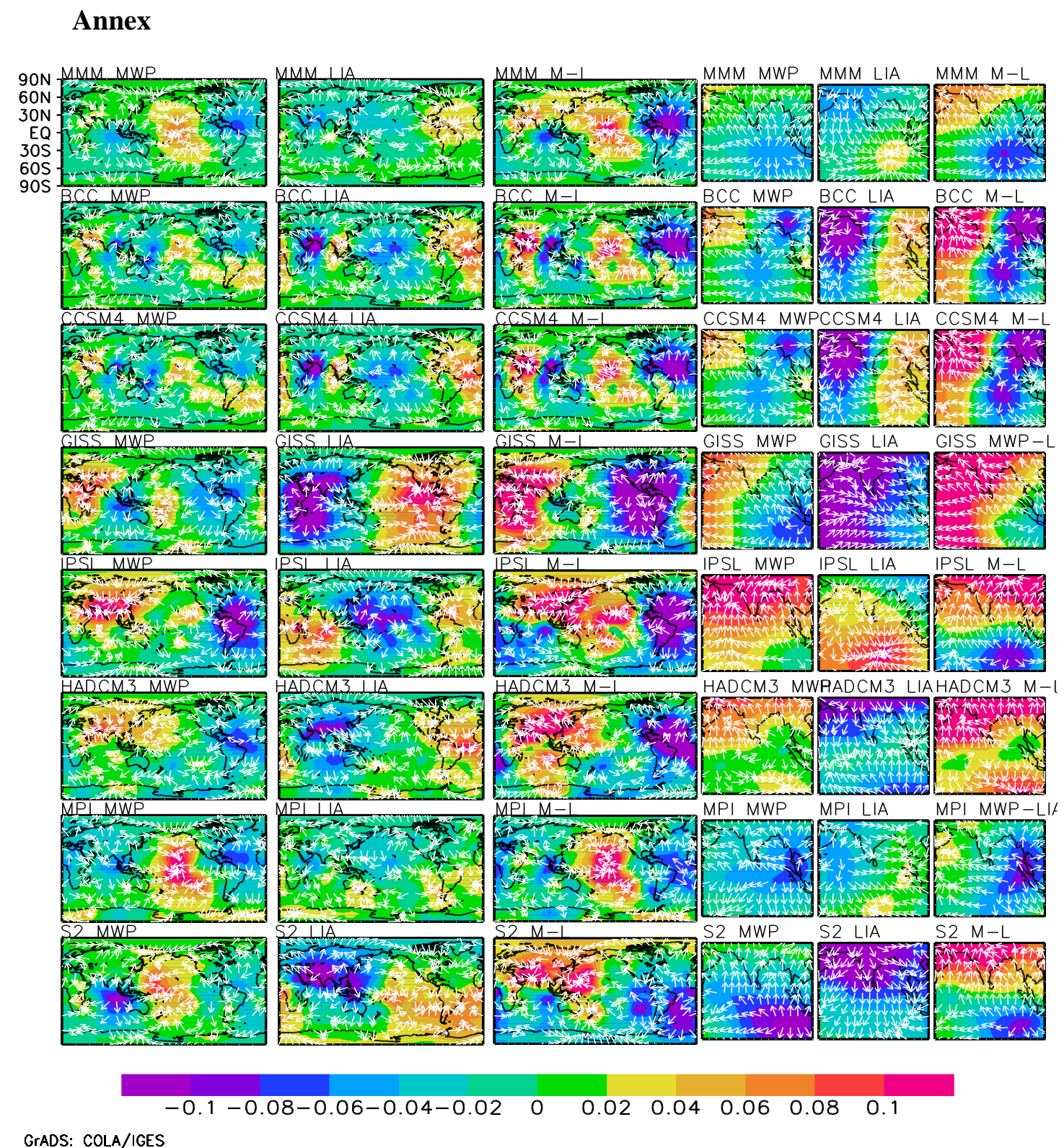

Figure A1:- Anomalous fields of JJAS rainfall (mm/day; contours) $850 \mathrm{hPa}$ divergent winds (ms-1) and velocity

5 potential (m2s-1; Shaded) of individual models during MWP, during LIA, and respective differences between the MWP \& LIA (MWP-LIA) of global and zoomed into the Indian \& tropical Indian Ocean regions. 
Clim. Past Discuss., doi:10.5194/cp-2017-24, 2017

Manuscript under review for journal Clim. Past

Discussion started: 31 March 2017

(c) Author(s) 2017. CC-BY 3.0 License.
Climate of the Past

Discussions
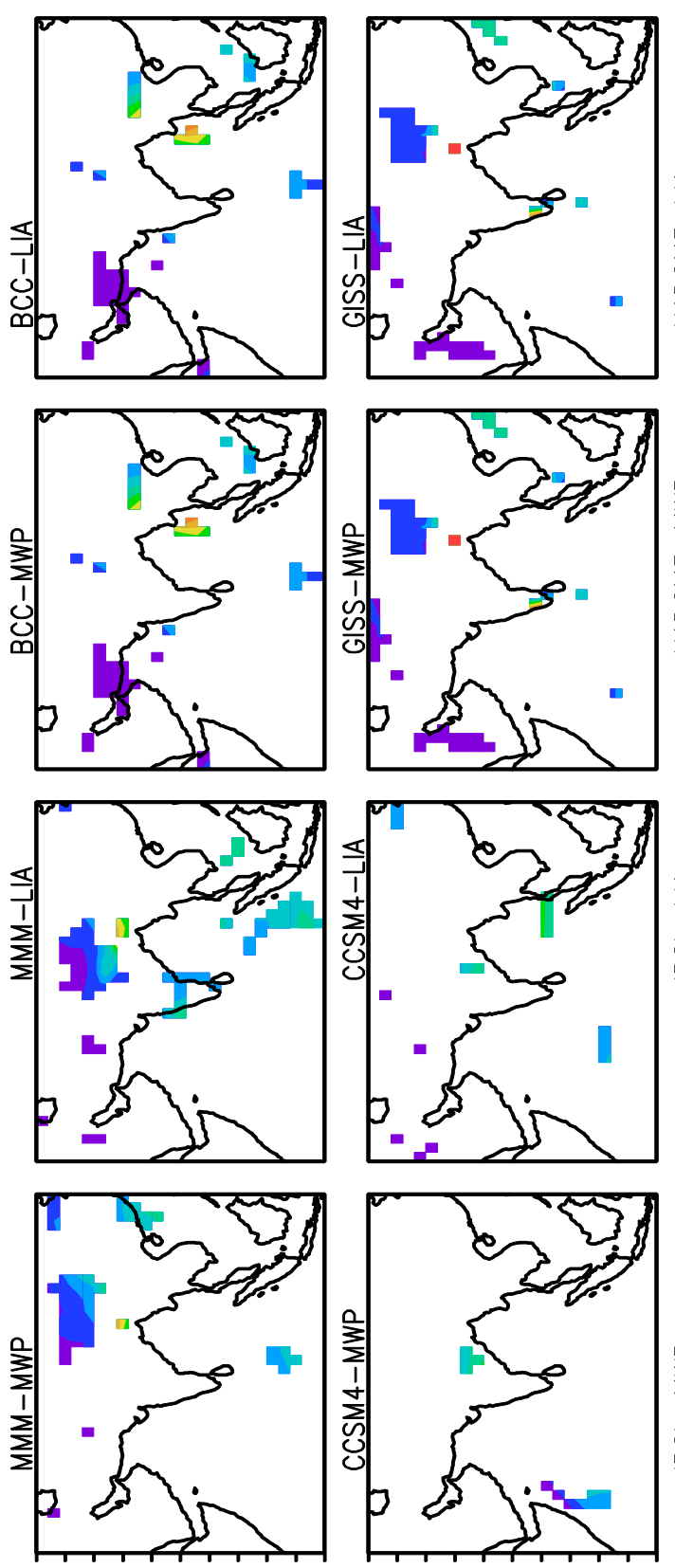

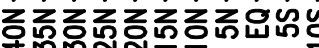
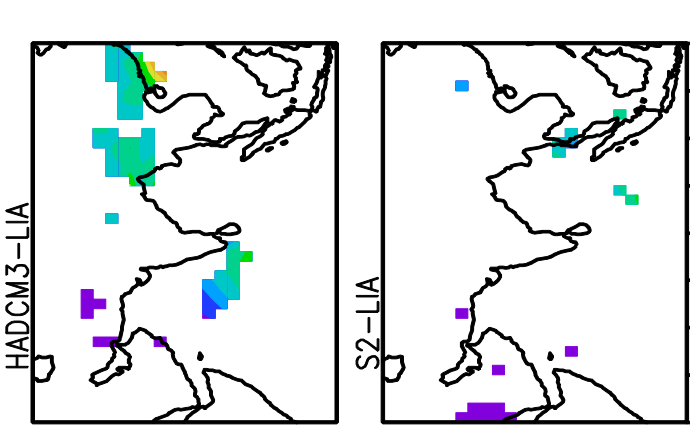

$\stackrel{\infty}{-}$
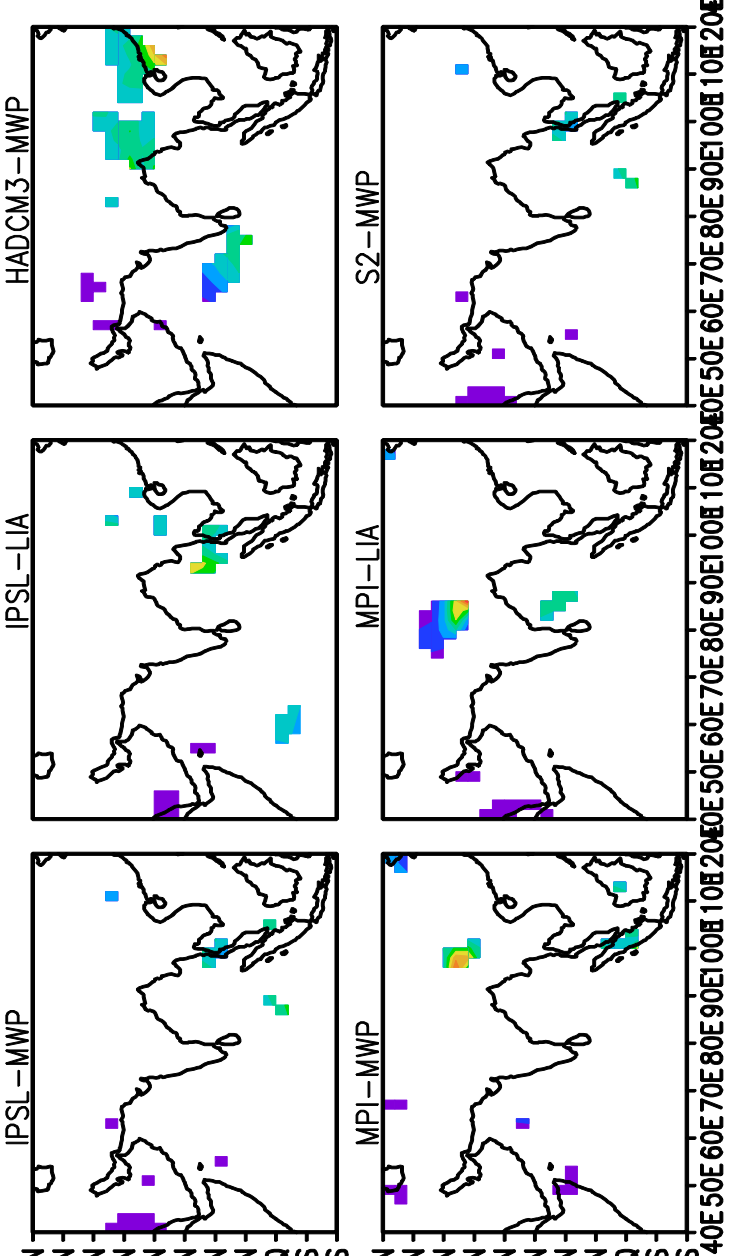

N

○

$\stackrel{\omega}{\sigma}$

I

N

으

$\infty$

$\boldsymbol{\omega}$

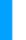

$+$

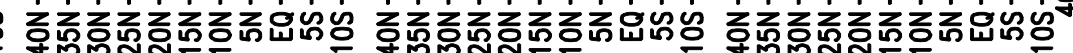

Figure A2: - 2-tailed Student's t-test for precipitation of each model over Indian domain at significant level of 0.10 for each model during MWP and LIA. 
Clim. Past Discuss., doi:10.5194/cp-2017-24, 2017

Manuscript under review for journal Clim. Past

Discussion started: 31 March 2017

(c) Author(s) 2017. CC-BY 3.0 License.

Climate of the Past

Discussions

\section{(c) (i)}
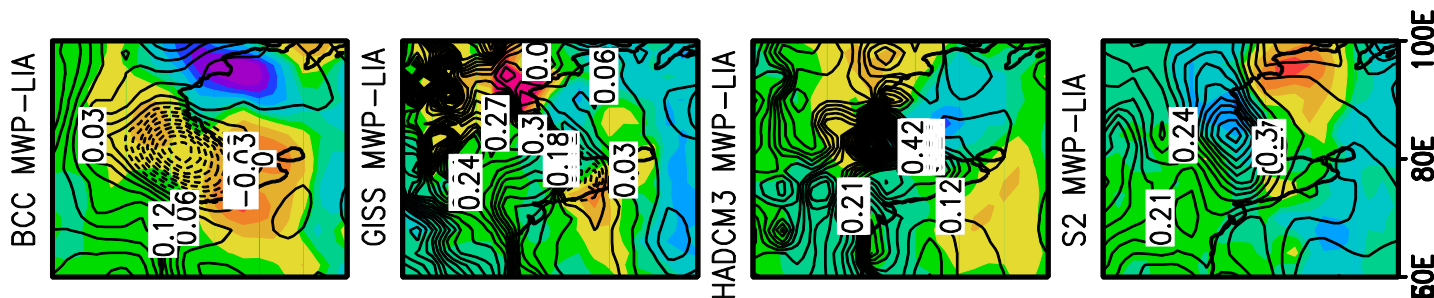

9.
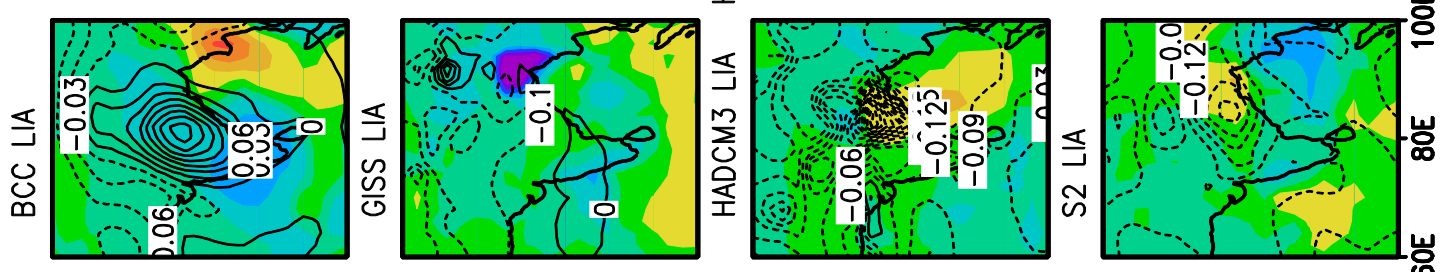

$\tilde{0}$

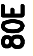

ก)
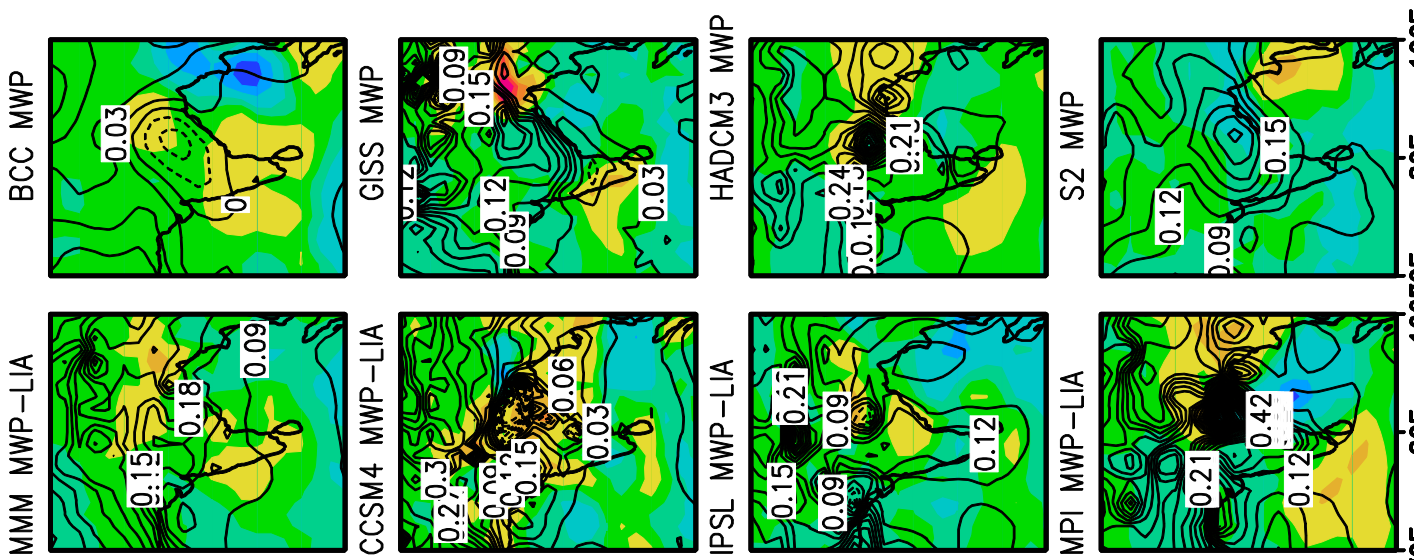

낭

$m$
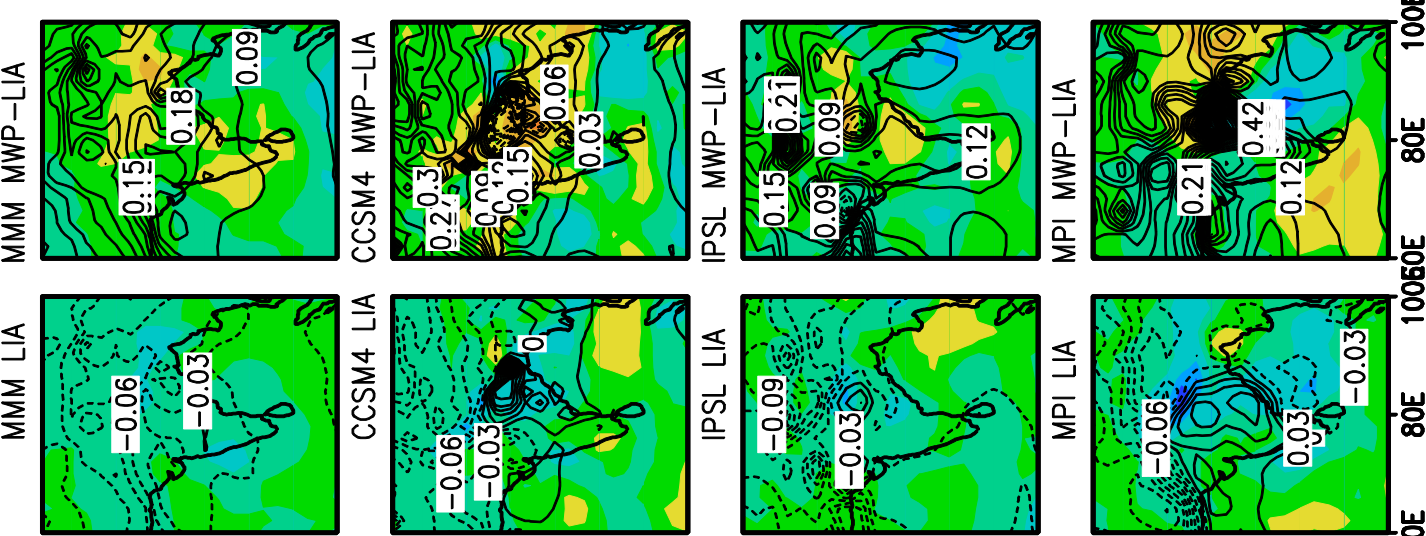

늉

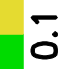
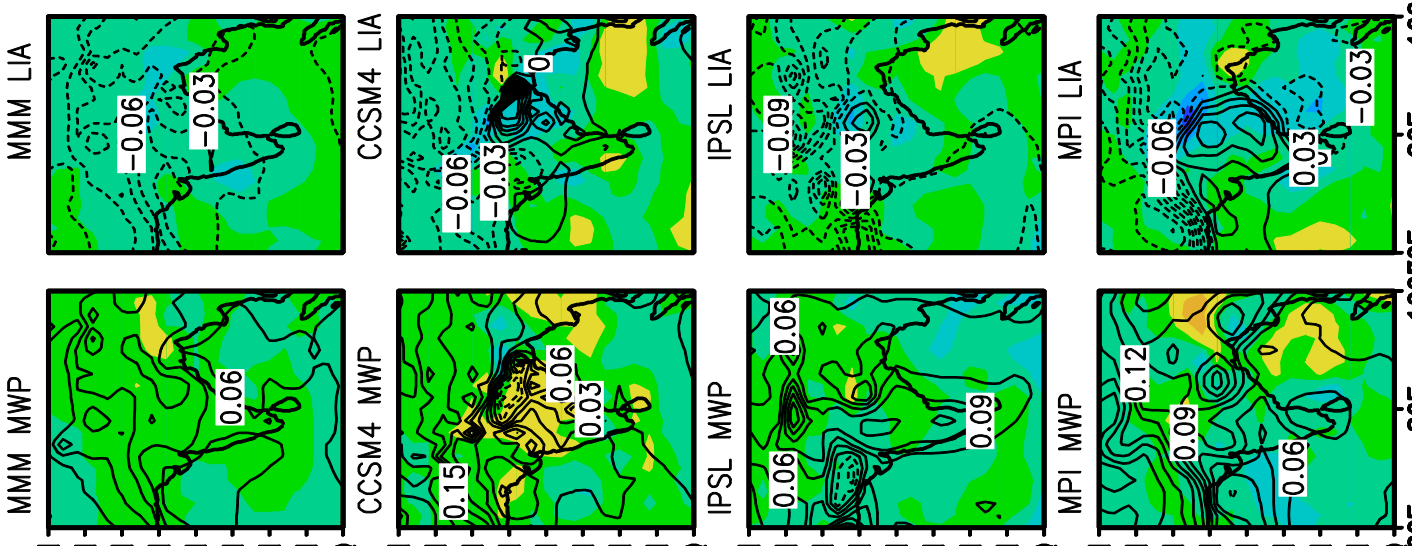

岕

m

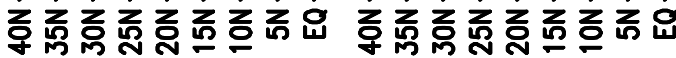

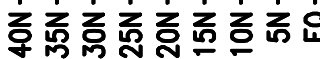

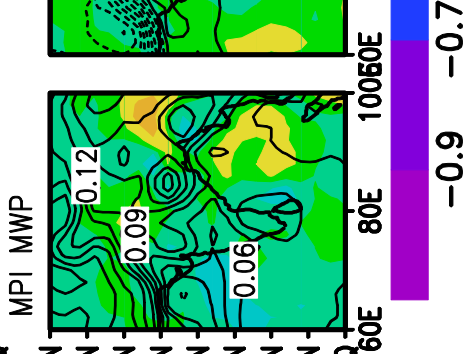

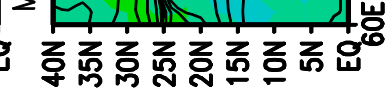

Figure A3: - Anomalous fields of JJAS surface temperature $\left({ }_{0} \mathrm{C}\right)$ and rainfall (mm/day; shaded) zoomed over Indian region during MWP, LIA and respective differences between the MWP \& LIA (MWP-LIA). 
Clim. Past Discuss., doi:10.5194/cp-2017-24, 2017

Manuscript under review for journal Clim. Past

Discussion started: 31 March 2017

(c) Author(s) 2017. CC-BY 3.0 License.

\section{References}

Ashok K, Guan Z, Yamagata T (2001) Impact of the Indian Ocean dipole on the relationship between the Indian monsoon rainfall and ENSO. Geophys Res Lett 28(23):4499-4502

Ashok K, Guan Z, Saji NH, Yamagata T (2004) Individual and combined influences of ENSO and the Indian Ocean dipole on the Indian summer monsoon. J Clim 17(16):3141-3155

Ashok K, Behera S, Rao AS, Weng HY, Yamagata T (2007) El Nino Modoki and its teleconnection. J Geophys Res 112:C11007. doi: 10.1029/2006JC003798

Berkelhammer,M., Sinha, A.,Mudelsee, M., Cheng, H., Edwards, R.L., Cannariato, K., 2010. Persistentmultidecadal power of the Indian SummerMonsoon. Earth Planet. Sci. Lett. 290, 166-172.

Berkelhammer, M., Sinha, A., Stott, L., Cheng, H., Pausata, F.S.R., Yoshimura, K., 2012. An abrupt shift in the Indian monsoon 4000 years ago. Geophys. Monogr. Ser. 198, 75-87.

Borgaonkar, H.P., Sikdera, A.B., Rama, S., Panta, G.B., 2010. El Niño and related monsoon drought signals in 523-year-long ring width records of teak (Tectona grandis L. F.) trees from south India. Palaeogeogr. Palaeoclimatol. Palaeoecol. 285, 74-84

Cai, W. et al. ENSO and greenhouse warming. Nature Clim. Change 5, 849-859 (2015)

Collins, M. (2000). The El Nino Southern Oscillation in the Second Hadley Centre Coupled Model and Its Response to Greenhouse Warming, (1997), 1299-1312.

Denniston Rhawn F. , Caroline C. Ummenhofer, Alan D. Wanamaker, Matthew S. Lachniet, Gabriele Villarini, Yemane Asmerom, Victor J. Polyak, Kristian J. Passaro, John Cugley, David Woods \& William F. Humphreys (2016). Expansion and Contraction of the Indo-Pacific Tropical Rain Belt over the Last Three Millennia, Scientific Reports 6, Article number: 34485 (2016) doi:10.1038/srep34485

Dixit, Y., 2013.Holocenemonsoon variability inferred frompaleolake sediments inNorth- western India PhD thesis University of Cambridge, UK.

25 Dixit, Y., Hodell, D.A., Petrie, C.A., 2014a. Abrupt weakening of the summer monsoon in northwest India $\sim 4100$ yr ago. Geology 42, 339-342.

Dixit, Y., Hodell, D.A., Sinha, R., Petrie, C.A., 2014b. Abrupt weakening of the Indian sum- mermonsoon at 8.2 kyrB.P. Earth Planet. Sci. Lett. 391, 16-23.

Dixit, Y., Hodell, D., Sinha, R., Petrie, C., 2015. Oxygen isotope analysis of multiple, single ostracod valves as a proxy for combined variability in seasonal temperature and lake water oxygen isotopes. J. Paleolimnol. 53, 35-45.

Dixit, Y., \& Tandon, S. K. (2016). Earth-Science Reviews Hydroclimatic variability on the Indian subcontinent in the past millennium?: Review and assessment. Earth Science Reviews, 161, 1-15. http://doi.org/10.1016/j.earscirev.2016.08.001

Dutt, S., Gupta, A.K., Clemens, S.C., Cheng,H., Singh, R.K., Kathayat, G., Edwards, R.L., 2015. Abrupt changes in Indian summermonsoon strength during 33,800 to 5500 years BP. Geophys. Res. Lett. 42, 
Clim. Past Discuss., doi:10.5194/cp-2017-24, 2017

Manuscript under review for journal Clim. Past

Discussion started: 31 March 2017

(c) Author(s) 2017. CC-BY 3.0 License.

$5526-5532$

Emile-Geay, J., M. Cane, R. Seager, A. Kaplan, and P. Almasi (2007), El Nino as a mediator for the solar influence on climate, Paleoceanography, 22, PA3210, doi:10.1029/2006PA001304

Fedorov, A. V. \& Philander, S. G. Is El Nin o changing? Science 288, 1997-2002 (2000)

5 Fleitmann, D., Burns, S.J., Mudelsee,M., Neff, U., Kramers, J.,Mangini, A., Matter, A., 2003. Holocene forcing of the Indian monsoon recorded in a stalagmite from southern Oman. Science 300, 1737-1739.

Fleitmann, D., Burns, S.J., Mangini, A., Mudelsee, M., Kramers, J., Villa, I., Neff, U., Subbary, A.-A., Buettner, A., Hippler, D., Matter, A., 2007. Holocene ITCZ and Indian monsoon dynamics recorded in stalagmites from Oman and Yemen (Socotra). Quat. Sci. Rev. 26, 170-188

10 Goswami BN, Venugopal V, Sengupta D, Madhusoodanan MS, Xavier PK (2006) Increasing trend of extreme rain events over India in a warming environment. Science 314(5804):1442-1445

Gupta, A.K., Anderson, D.M., Overpeck, J.T., 2003. Abrupt changes in the Asian southwest monsoon during the Holocene and their links to the North Atlantic Ocean. Nature 421, 354-357.

Graham, N.E., Ammann, C.M., Fleitmann, D., Cobb, K.M., Luterbacher, J., 2010. Support for global climate reorganization during the Medieval Climate Anomaly. Clim. Dyn. 37, 1217-1245.

Grove, J.M., 1988. The Little Ice Age.Menthuen, London.

Guhathakurta, P. and Rajeevan, M. (2008), Trends in the rainfall pattern over India. Int. J. Climatol., 28: 1453-1469. doi:10.1002/joc. 1640

Hersbach H. (2015). ERA-20CM : a twentieth-century atmospheric model ensemble, (July), 2350-2375. http://doi.org/10.1002/qj.2528.

IPCC, 2013: Climate Change 2013: The Physical Science Basis. Contribution of Working Group I to the Fifth Assessment Report of the Intergovernmental Panel on Climate Change [Stocker, T.F., D. Qin, G.K. Plattner, M. Tignor, S.K. Allen, J. Boschung, A. Nauels, Y. Xia, V. Bex and P.M. Midgley (eds.)]. Cambridge University Press, Cambridge, United Kingdom and New York, NY, USA, 1535 pp, doi:10.1017/CBO9781107415324.

Jourdain, N. C., Sen, A., Moise, A. F., \& Ashok, K. (2013). The Indo-Australian monsoon and its relationship to ENSO and IOD in reanalysis data and the CMIP3 / CMIP5 simulations, 3073-3102. http://doi.org/10.1007/s00382-013-1676-1.

Kitoh, A. (2007). Variability of Indian monsoon-ENSO relationship in a 1000-year MRI-CGCM2.2 simulation. Natural Hazards, 42(2), 261-272. http://doi.org/10.1007/s11069-006-9092-z

Krishnan R., Sabin T.P., Vellore R., Mujumdar M., Sanjay J., Goswami B.N. (2016), Deciphering the desiccation trend of the South Asian monsoon hydroclimate in a warming world, Climate Dynamics, 47, DOI:10.1007/s00382-015-2886-5, 1007-1027

Kumar, K. K., Rajagopalan, B., \& Cane, M. A. (1999). On the Weakening Relationship Between the Indian Monsoon and ENSO, 284(June), 2156-2160.

Lamb, H.H., 1965. The early medieval warm epoch and its sequel. Palaeogeogr. Palaeoclimatol. 1, 13-37. 
Clim. Past Discuss., doi:10.5194/cp-2017-24, 2017

Manuscript under review for journal Clim. Past

Discussion started: 31 March 2017

(c) Author(s) 2017. CC-BY 3.0 License.

Lehmann, J., Coumou, D., \& Frieler, K. (2015). Increased record-breaking precipitation events under global warming. Climatic Change. doi: 10.1007/s10584-015-1434-y

Lewis, S. C., \& Legrande, A. N. (2015). Stability of ENSO and its tropical Pacific teleconnections over the Last Millennium. Climate of the Past, 11(10), 1347-1360. http://doi.org/10.5194/cp-11-1347-2015.

5 Min Y M. (2008). A Probabilistic Multimodel Ensemble Approach to Seasonal Prediction, 812-828. http://doi.org/10.1175/2008WAF2222140.1

Nakamura, A., Yokoyama, Y., Maemoku, H., Yagi, H., Okamura, M., Matsuoka, H., Miyake, N., Osada, T., Adhikari, D.P., Dangol, V., 2015.Weakmonsoon event at 4.2 ka recorded in sediment from Lake Rara, Himalayas. Quat. Int. http://dx.doi.org/10.1016/j.quaint. 2015.05.053.

10 Neff, U., S. J. Burns, A. Mangini, M. Mudelsee, D. Fleitmann, and A. Matter (2001), Strong coherence between solar variability and the monsoon in Oman between 9 and 6 kyr ago, Nature, 411, 290-293

Ponton, C., Giosan, L., Eglinton, T.I., Fuller, D.Q., Johnson, J.E., Kumar, P., Collett, T.S., 2012. Holocene aridification of India. Geophys. Res. Lett. 39, L03704.

Power, S., Delage, F., Chung, C., Kociuba, G., and Keay, K.: Robust twenty-first-century projections of El Niño and related precipitation variability, Nature, 502, 541-545, doi:10.1038/nature12580, 2013.

Prasad, S., Enzel, Y., 2006. Holocene paleoclimates of India. Quat. Res. 66 (3), 442-453.

Prasad, S., Anoop, A., Riedel, N., Sarkar, S.,Menzel, P., Basavaiah,N., Krishnan, R., Fuller, D., Plessen, B., Gaye, B., Röhl, U.,Wilkes,H., Sachse, D., Sawant, R.,Wiesner, B., Stebich, M., 2014. Prolonged monsoon droughts and links to Indo-Pacific warm pool: a Holocene record fromLonar Lake, Central India. Earth Planet. Sci. Lett. 391, 171-182

Rajeevan, M., Bhate, J., Kale, J. D., \& Lal, B. (2006). High resolution daily gridded rainfall data for the Indian region?: Analysis of break and active monsoon spells, 91(3).

Ramesh, R and Tiwari, M and Chakraborty, S and Managave, SR and Yadava, MG and Sinha, DK (2010) Retrieval of south asian monsoon variation during the holocene from natural climate archives. Current Science, 99 (12). pp. 1770-1786.

Revadekar, J. V, Kothawale, D. R., Patwardhan, S. K., Pant, G. B., \& Kumar, K. R. (2012). extremes over India, 1133-1155. http://doi.org/10.1007/s11069-011-9895-4

Sano, M., Ramesh, R., Sheshshayee, M., and Sukumar, R.: Increasing aridity over the past 223 years in the Nepal Himalaya inferred from a tree-ring $\delta 18 \mathrm{O}$ chronology, The Holocene, 1-9. 2011

30 Sarkar, A., Ramesh, R., Somayajulu, B. L. K., Agnihotri, R., Jull, A. J. T., \& Burr, O. S. (2000). High resolution Holocene monsoon record from the eastern Arabian Sea. Earth and Planetary Science Letters, 177(3-4), 209-218. DOI: 10.1016/S0012-821X(00)00053-4.

Sinha, A., Cannariato, K.G., Stott, L.D., Cheng, H., Edwards, R.L., Yadava, M.G., Ramesh, R., Singh, I.B., 2007. A 900-year (600 to $1500 \mathrm{AD}$ ) record of the Indian summermonsoon precipitation from the coremonsoon zone of India. Geophys. Res. Lett. 34.

Sinha, A., Berkelhammer, M., Stott, L.,Mudelsee,M., Cheng, H., Biswas, J., 2011a. The lead- ingmode of 
Clim. Past Discuss., doi:10.5194/cp-2017-24, 2017

Manuscript under review for journal Clim. Past

Discussion started: 31 March 2017

(c) Author(s) 2017. CC-BY 3.0 License.

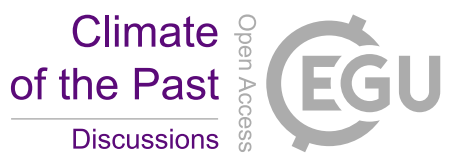

Indian SummerMonsoon precipitation variability during the lastmillen- nium. Geophys. Res. Lett. 38.

Sinha, A., Stott, L., Berkelhammer, M., Cheng, H., Edwards, R.L., Buckley, B., Aldenderfer, M.,Mudelsee,M., 2011b. A global context formegadroughts inmonsoon Asia during the past millennium. Quat. Sci. Rev. 30, 47-62.

Staubwasser, M., Sirocko, F., Grootes, P.M., Segl, M., 2003. Climate change at the 4.2 ka BP termination of the Indus valley civilization and Holocene south Asianmonsoon vari- ability. Geophys. Res. Lett. 30, 1425. http://dx.doi.org/10.1029/2002GL016822.

Stocker, T.F., D. Qin, G.-K. Plattner, L.V. Alexander, S.K. Allen, N.L. Bindoff, F.-M. Bréon, J.A. Church, U. Cubasch, S. Emori, P. Forster, P. Friedlingstein, N.Gillett, J.M. Gregory, D.L. Hartmann, E. Jansen, B. Kirtman, R. Knutti, K. Krishna Kumar, P. Lemke, J. Marotzke, V. Masson-Delmotte, G.A. Meehl, I.I. Mokhov, S. Piao, V. Ramaswamy, D. Randall, M. Rhein, M. Rojas, C. Sabine, D. Shindell, L.D. Talley, D.G. Vaughan and S.-P. Xie, 2013: Technical Summary. In: Climate Change 2013: The Physical Science Basis. Contribution of Working Group I to the Fifth Assessment Report of the Intergovernmental Panel on Climate Change [Stocker, T.F., D. Qin, G.-K. Plattner, M. Tignor, S.K. Allen, J. Boschung, A. Nauels, Y. Xia, V. Bex and P.M. Midgley (eds.)]. Cambridge University Press, Cambridge, United Kingdom and New York, NY, USA, pp. 33-115, doi:10.1017/ CBO9781107415324.005.

Taylor, K. E., Stouffer, R. J., and Meehl, G. A.: An overview of CMIP5 and the experiment design, B. Am. Meteor. Soc., 93, 485-498, doi:10.1175/BAMS-D-11-00094.1, 2012.

Titchner, H. A., and N. A. Rayner (2014), The Met Office Hadley Centre sea ice and sea surface temperature data set, version 2: 1. Sea ice concentrations, J. Geophys. Res. Atmos., 119, 2864-2889, doi:10.1002/2013JD020316.

Tiwari, M., Ramesh, R., Somayajulu, B., Jull, A., Burr, G., 2005. Solar control of southwest monsoon on centennial timescales. Curr. Sci. 89, 1583-1588.

Vecchi, G. A., Soden, B. J., Wittenberg, A. T., Held, I. M., Leetmaa, A., \& Harrison, M. J. (2006). Weakening of tropical Pacific atmospheric circulation due to anthropogenic forcing, 441(May), 73-76. http://doi.org/10.1038/nature04744

Wittenberg, A. T. (2009), Are historical records sufficient to constrain ENSO simulations? Geophys. Res. Lett., 36, L12702, doi:10.1029/2009GL038710.

30 Yadava, M. G. and Ramesh, R. R., Monsoon reconstruction from radiocarbon dated tropical speleothems. The Holocene, 2005, 15,48-59. 